\title{
Review: \\ Ethno-zoological study of animals-based medicine used by traditional healers of Northeast India
}

\author{
JAFRIN FARHA HUSSAIN", HERO TYNSONG ${ }^{* v}$ \\ Ministry of Environment, Forest and Climate Change, Integrated Regional Office, Law-U-Sib, Madanriting, Shillong-793021, Meghalaya, India \\ "email: jafrinfarhahussain@gmail.com: ${ }^{\text {}}$ h.tynsong78@gmail.com
}

Manuscript received: 29 October 2020. Revision accepted: 1 December 2020

\begin{abstract}
Hussain JF, Tynsong H. 2021. Review: Ethno-zoological study of animals-based medicine used by traditional healers of Northeast India. Asian J Ethnobiol 4: 1-22. For ages, plants and animals have been used in human cultures as therapeutics. Animals have not only acted as a source of food for humans but have also been commonly used in applications such as medicine, clothes, and other related services. The use of animals and animal products in traditional methods of treating diseases, and for many different reasons, dates back to the early days of civilization. Treatment of human diseases using animal-derived products is called zootherapy or ethno-zoology. Despite the worldwide utilization of ethno-zoology in the form of traditional medicines based on animals, a thorough study of zootherapy in comparison to plant-based medicinal research is still ignored. This study highlights available knowledge on ethno-zoological therapeutic applications used by different traditional healers of North-East (NE) India. Concerning the frequency of animal species, the use of mammals and mammalian products is the highest in NE India compared to other animal groups. In contrast, the use of fish-based medicine in the state of Manipur is prevalent compared to other animal species. In Arunachal Pradesh, the use of insects is high in traditional medicines.
\end{abstract}

Keywords: Animals-based medicines, ethno-zoology, North-East India, traditional knowledge

\section{INTRODUCTION}

The treatment of human diseases using animals and animal-derived treatments is known as zoo therapy (CostaNeto 1999). World Health Organisation (WHO 1993) reported that around $70-80 \%$ of the world's rural population relies for primary health care on traditional medicine. Using animals and their products to treat patients suffering from various health problems has a long tradition. It is still prevalent in many parts of the world, even when medical science has achieved great heights (Jugli et al., 2019). WHO (2014) estimates that in developing countries, the proportion of the population using traditional medicine is considerably higher $(60-90 \%)$ compared to developed countries (23-80\%).

Knowledge of traditional medicines by indigenous communities worldwide that help them heal, avoid, and mitigate diseases is derived from their cultural traditions, indigenous values, ideas, and rituals (Young 1983; Janes 1999). Animal-based treatments are successful in several applications, and in recent times, they constitute a significant part of traditional pharmaceutical products (WRI 2000). Anageletti et al. (1992) and Rosner (1992) reported that animals and their products had been used internationally in traditional treatments, playing significant roles in healing practices, magic rituals, and religious practices amongst various cultures and communities.

Animal-based medicines are usually obtained from three sources: (i) the entire body or its smaller parts, (ii) metabolic products such as secretions or excreta, and (iii) other items produced by animals like nests, coconuts, honey, eggs, etc. (Costa-Neto 2005). In recent times, the application of zootherapy has been considered the foremost reliable primary alternative among many other known therapeutic practices in the world (Kendie et al., 2018). The traditional knowledge of indigenous people around the globe has played a crucial role in identifying living organisms endowed with medicinal values; and is essential for treating human health problems (Kendie et al. 2018).

Over several hundred years, communities and societies have slowly developed a large store of information on animals that could be closely combined with different aspects of cultures and customs, thereby providing new possibilities for other cultural strategies(Alves 2012). WHO has previously selected 252 essential chemicals for medicinal purposes, of which $11 \%$ are of plant origin, and 9\% are of animal origin (Marques 1997). While this shows that traditional based medicines derived from plants and their derivatives have been studied in more detail (Werner 1970; Ragupathy et al. 2008; Ragupathy and Newmaster 2009; Polat et al. 2015; Silambarasan and Ayyanar 2015; Bhatti et al. 2017; Faruque et al. 2018), however, the identification of animal resources for medicinal and human health care is equally important and requires extensive research (Alves and Rosa 2005; Costa-Neto 2005).

India is home to large ethnic and indigenous communities (von Fürer-Haimendorf 1982) relying heavily on plants and animals for their medicine (Sarmah et al. 2006; Tynsong et al. 2006), food (Dutta and Dutta 2005; Tynsong et al. 2012a, b), shelter (Cavendish 2000), 
clothing (Mao et al. 2009), etc. Borah and Prasad (2017) reported that many indigenous communities in India have recently begun opting for traditional animal-based medicines as an alternative to other health care systems. Animal byproducts such as hooves, scales, bones, feathers, tusks, etc. have acted as essential ingredients for the preparation of some curative medicines and drugs (Adeola 1992; Anageletti et al. 1992; Kang and Phipps 2003). Documentation of the country's traditional methods of healing using animalbased medication is essential for establishing new medicinal prospects and remedial measures for several unknown diseases (Borah and Prasad 2017).

The Indian traditional knowledge system on medicine has declines due to the steady increase of urbanization and other anthropogenic factors (Das 2015). Therefore, it is vital to understand and record the knowledge available on animal-based therapeutics practiced by local healers among different indigenous communities before these traditional cultures and practices are forbidden and lost (Trivedi 2002). However, overexploitation of animals may jeopardize species' survival rate, causing ecosystem imbalances (Tynsong et al. 2020). Therefore, to preserve the proper harmonious life of humans and animals in the use of animal-based medicines, documentation is necessary to understand the everyday use of animals and animal products by local healers as a source of traditional therapy (Chakravorty et al. 2011a, b).

Studies on plant-based traditional medicine have been comparatively more in North-east (NE) India (Dutta and Dutta 2005; Sajem and Gossai 2006; Mao et al. 2009; Chakraborty et al. 2012; Prakash et al. 2014; Tynsong et al. 2020) compared to animal-based traditional medicines (Lalramnghinglova 1999). The lack of information is mainly because knowledge of animals-based traditional medicine is usually passed orally from one generation to the next, and this information is slowly lost as the knowledge bearers die (Borah and Prasad 2017). The present study is aimed to review and discuss the status of traditional animal-based medicines in NE India.

\section{STUDY AREA}

NE India is part of the Indo-Burma biodiversity hotspot and accounts for $8 \%$ (about 262,179 sq. km) of India's total geographic area (Tynsong et al. 2020). NE India has eight states, namely Arunachal Pradesh, Assam, Manipur, Mizoram, Meghalaya, Nagaland, Tripura, and Sikkim (Figure 1). Arunachal Pradesh is a culturally rich state of $\mathrm{NE}$, India, and is the largest (area-wise) with rich alpine geographical diversity and a wider variety of wildlife (Saio and Upadhyay 2018). NE India is considered a home to many indigenous communities and groups with varying social-cultural practices, following a wide variety of cultural diversity, and leading a life largely dependent on the biological resources around them (Ripunjoy and Indira 2012; Teron and Borthakur 2012).

Mao et al. (2009) recorded that NE India is inhabited by more than 200 indigenous communities with distinct cultural entities, the while the 2011 census reports that NE
India is home to 427 tribal groups with their own traditional and cultural identities (Borah and Prasad 2017). These indigenous communities possess a wide range of traditional knowledge on traditional medicines (Tynsong et al. 2020). It is crucial to record such an information structure before it gets lost forever inside the rapid push of modernization and globalization. The number of significant and sub-indigenous communities in NE India as reported by various researchers is summarized in Table 1 .

North-east India's indigenous people have long been dependent on traditional medicine for their overall health and wellbeing (Jamir and Lal 2005; Kalita et al. 2005; Mao et al. 2009; Tynsong et al. 2020). For example, Arunachal Pradesh's Nyishi and Galo communities use edible and therapeutic insects and vertebrate species to treat various ailments (Chakravorty et al. 2011a), while ethnic communities of Nagaland use different animals to treat asthma, tuberculosis, rheumatic pain, and paralysis (Jamir and Lal 2005). In Meghalaya, the use of animals for various ailments is recorded among the Khasi community in their natural, zoo-therapeutic traditional methods (Mihsill and Keshan 2017; Turnia and Prasad 2017). A wide variety of traditional plant-based medicines (Sajem and Gossai 2006), animals, and often mixed plant and animal formulations (Kalita et al. 2005) were recorded from the state of Assam. Ethno-zoological applications reported from Manipur, Sikkim, Mizoram, and Tripura are also discussed in this paper.

\section{DATA ANALYSIS}

\section{Data sources}

The present research work is focused on the original reports and findings and review papers. In this study, a survey of the initial investigations was mainly considered. The definitions are based on the authors' study of the knowledge on ethno-zoology available in NE India. Most of the literature has been cited/downloaded from journals and online sources such as Research Gate, Google Scholar, Academia.edu, and the respective journals' official websites. The IUCN Red List of Endangered Species (IUCN 2020) was used to determine the conservation status of the different animal species used for traditional medicine by various indigenous groups of NE India.

\section{State-wise analysis}

State-wise analysis in the results has been presented in alphabetical order according to the names of the NorthEastern Indian States. With the aid of Microsoft (MS) Excel, quantitative evaluation of data concerning the use of animal groups among different indigenous communities in NE India has been conducted. The analysis of the present paper was intended to include and incorporate the available knowledge recorded in NE India on traditional medicine using animals. The present report is based on the compilation of literature surveys of general knowledge on ethno-zoological activities prevalent in all eight North-east Indian states from 1999 to October 2020; and is discussed hereunder. 


\section{DETAILED REPORT OF EACH STATE}

A survey on the available literature of ethno-zoological applications by traditional healers in all the Northeast Indian states has helped identify various animal groups used for medicinal purposes. A The present paper has discussed a detailed report on available literature pertaining to each state.

A summary of the available literature and research findings on ethno-zoological studies in NE India, with details of animal groups and their body parts used for several diseases, are presented in Table 2.

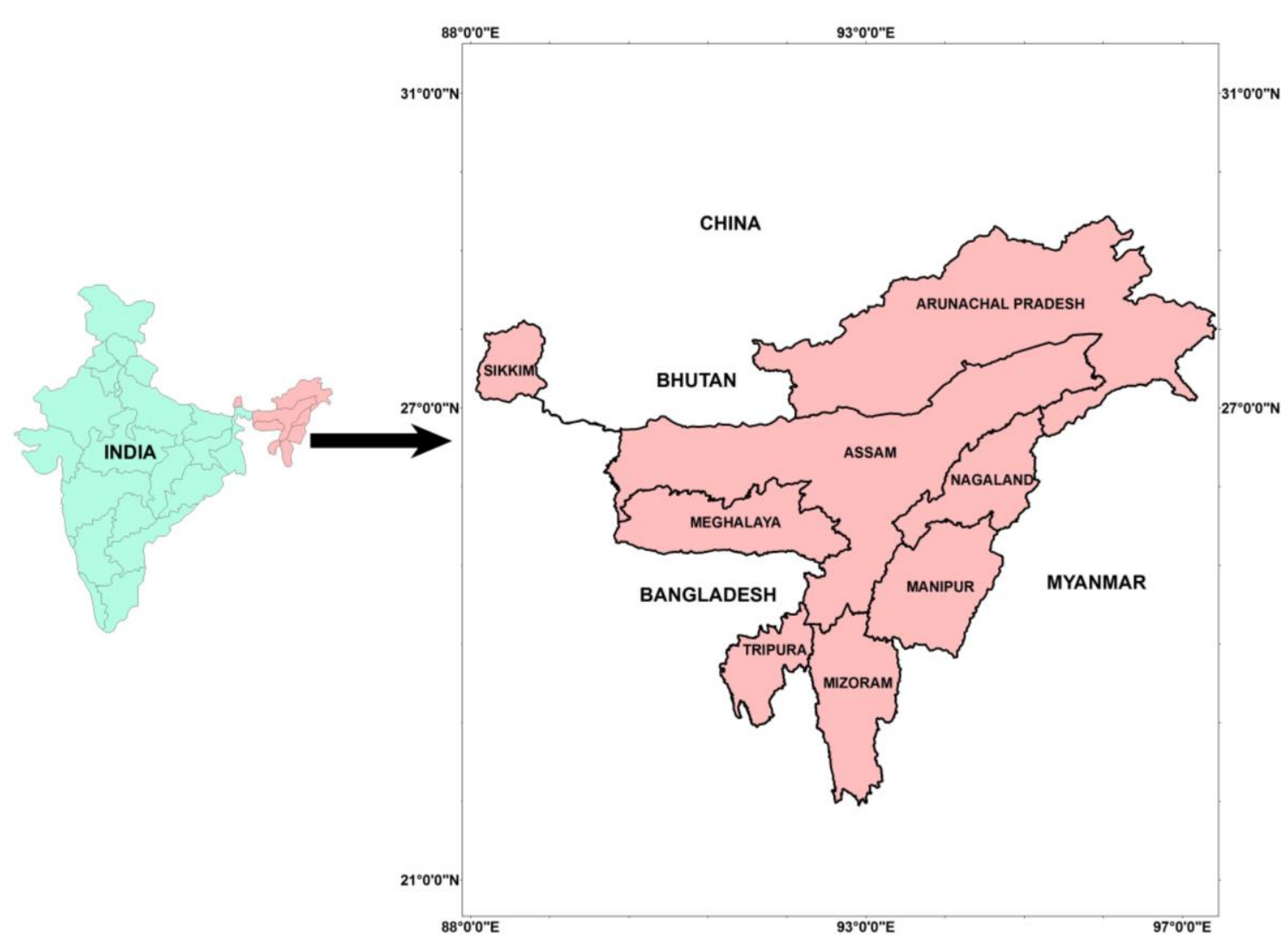

Figure 1. Location map of North-east India

Table 1. Number of major and sub-indigenous communities in North-east India as reported by various researchers

\begin{tabular}{lccl}
\hline State & $\begin{array}{c}\text { No. of major } \\
\text { indigenous } \\
\text { communities }\end{array}$ & $\begin{array}{c}\text { No. of sub- } \\
\text { indigenous } \\
\text { communities }\end{array}$ & Referred literature(s) \\
\hline Arunachal Pradesh & 20 & 17 & Dutta and Dutta (2005), Tynsong et al. (2020) \\
Assam & 62 & 16 & Dutta and Dutta (2005), Tynsong et al. (2020) \\
Manipur & 29 & - & Dutta and Dutta (2005), Tynsong et al. (2020) \\
Meghalaya & 22 & - & Dutta and Dutta (2005), Chakraborty et al. (2012), Tynsong et al. (2020) \\
Mizoram & 15 & 45 & Dutta and Dutta (2005), Chakraborty et al. (2012), Tynsong et al. (2020) \\
Nagaland & 36 & 16 & Chakraborty et al. (2012), Tynsong et al. (2020) \\
Sikkim & 3 & - & Dutta and Dutta (2005), Chakraborty et al. (2012), Dhakal et al. (2019) \\
Tripura & 19 & - & Chakraborty et al. (2012), Das (2015), Tynsong et al. (2020) \\
\hline
\end{tabular}

Note: '-' signifies not reported 
Table 2. Ethno-zoological studies of animal groups and their body parts used for several diseases in NE India

\begin{tabular}{|c|c|c|c|c|c|}
\hline State & $\begin{array}{l}\text { Indigenous } \\
\text { community }\end{array}$ & $\begin{array}{l}\text { No. of animal } \\
\text { species used }\end{array}$ & Body parts used & Ailments/Diseases & Author(s) \\
\hline \multirow[t]{8}{*}{$\begin{array}{l}\text { Arunachal } \\
\text { Pradesh }\end{array}$} & Monpa & $\begin{array}{l}11 \\
\text { (mammals, birds) }\end{array}$ & $\begin{array}{l}\text { Meat, gall bladder, bones, musk, musk } \\
\text { gland of musk deer, fat. }\end{array}$ & $\begin{array}{l}\text { Malaria, typhoid, tuberculosis, fever, rheumatic pain, diarrhea, } \\
\text { smallpox, cholera, magico-religious purposes. }\end{array}$ & $\begin{array}{l}\text { Solanki and Chutia } \\
\text { (2004) }\end{array}$ \\
\hline & Nyishi & $\begin{array}{l}13 \\
\text { (mammals, birds, } \\
\text { reptiles) }\end{array}$ & $\begin{array}{l}\text { Skin, claw, teeth, meat, musk, pod, tusk, } \\
\text { gall bladder, fat. }\end{array}$ & $\begin{array}{l}\text { Rheumatic pain, dysentery, jaundice, intestinal troubles, } \\
\text { infections, liver and heart diseases, cough, hypertension, } \\
\text { malarial fever, swelling, burn, joint fractures, impotency. }\end{array}$ & $\begin{array}{l}\text { Solanki et al. } \\
\text { (2004) }\end{array}$ \\
\hline & Nyishi & $\begin{array}{l}18 \\
\text { (mammals, birds, } \\
\text { reptiles) }\end{array}$ & $\begin{array}{l}\text { Gall bladder, horn, penis, meat, bone, fat, } \\
\text { testis, exoskeleton, alimentary canal. }\end{array}$ & $\begin{array}{l}\text { Malaria, typhoid, dysentery, feminine problems, rheumatic } \\
\text { pain, pox, wounds, abdominal pain, weakness. }\end{array}$ & $\begin{array}{l}\text { Solanki et al. } \\
(2005)\end{array}$ \\
\hline & Galo & $\begin{array}{l}16 \\
\text { (insects) }\end{array}$ & Whole body, hive, larva, adult. & Additional nutrition for nutritional deficiency. & $\begin{array}{l}\text { Dagyom and Gopi } \\
\text { (2009) }\end{array}$ \\
\hline & $\begin{array}{l}\text { Apatani, Nyishi, } \\
\text { Monpa }\end{array}$ & $\begin{array}{l}100 \\
\text { reptiles, fish, } \\
\text { mollusks, } \\
\text { arthropods) }\end{array}$ & $\begin{array}{l}\text { Whole animal, meat, bone, fat, skin, gall } \\
\text { bladder, gut, shell, alimentary canal, penis, } \\
\text { horn, blood, mucus, feathers and legs } \\
\text { (birds). }\end{array}$ & $\begin{array}{l}\text { Jaundice, indigestion, stomach ailments, asthma, tuberculosis, } \\
\text { dysentery, boil, snake and scorpion bites, cough, headache, } \\
\text { bronchitis, stroke, hallucination, wound, pox, anemia, } \\
\text { weakness, skin disease, malaria, piles, rheumatic pain, typhoid, } \\
\text { nasal congestion, night blindness, paralysis, impotency. }\end{array}$ & $\begin{array}{l}\text { Solanki and Chutia } \\
\text { (2009) }\end{array}$ \\
\hline & $\begin{array}{l}\text { Nyishi, } \\
\text { Galo }\end{array}$ & $\begin{array}{l}81 \\
\text { (local insects) }\end{array}$ & $\begin{array}{l}\text { Whole insect, larval stages, nymphs, adult } \\
\text { stages, pupae, eggs. }\end{array}$ & $\begin{array}{l}\text { Cough, fever, stomach ailments, skin irritation, scabies, } \\
\text { toothache, high blood pressure, boil, wounds, malaria, } \\
\text { dysentery, chest pain. }\end{array}$ & $\begin{array}{l}\text { Chakravorty et al. } \\
\text { (2011a) }\end{array}$ \\
\hline & $\begin{array}{l}\text { Nyishi, } \\
\text { Galo }\end{array}$ & $\begin{array}{l}36 \\
\text { (vertebrates) }\end{array}$ & $\begin{array}{l}\text { Mucus, stomach, gut, fins, bones, whole } \\
\text { body, fats, flesh, feathers, testicles, frontal } \\
\text { bone, skin, intestine, nails, blood, bone } \\
\text { marrow. }\end{array}$ & $\begin{array}{l}\text { Burns, stomach ache, digestive problems, body burns, diarrhea, } \\
\text { smallpox, wound healing, joint pain, diseases in cattle, early } \\
\text { pregnancy, tuberculosis, gastritis, jaundice. }\end{array}$ & $\begin{array}{l}\text { Chakravorty et al. } \\
\text { (2011b) }\end{array}$ \\
\hline & Adi & $\begin{array}{l}39 \\
\text { (aquatic and } \\
\text { terrestrial) }\end{array}$ & $\begin{array}{l}\text { Bones, meat, skull, wings, eggs, tail, gall } \\
\text { bladder, ant larvae. }\end{array}$ & $\begin{array}{l}\text { Diabetes, weakness, fertility enhancement, malaria, skin } \\
\text { disease, joint pain, taboos and spiritual purposes. }\end{array}$ & $\begin{array}{l}\text { Chinlampianga et } \\
\text { al. (2013) }\end{array}$ \\
\hline
\end{tabular}


Wancho and Tangsa Tangsa:55

Wancho: 20

(vertebrates and

invertebrates)

\section{Assam}

Ethnic communities

of Dibrugarh

Karbi

Karbi

Biate

Karbi

Nath, Karbi

14 insect, mollusk, reptiles, crustaceans)

(fishes) birds)
Gall bladder, bile, body fat, flesh, liver, lactating breast, tooth, scales, blood, whole body, stomach, intestine,

wings/appendages, brain, urinary bladder,

excreta, bone marrow, limb bones, budding tender antlers (Sambar and Hog deer),

urine, tail fat (Pied hornbill and domestic

chicken), head and shell (tortoise), honey

\section{Edible portion of fish, blood.}

Decayed flesh, saliva, whole body, elephant teeth, raw blood, meat, feather

mammals, insects,

(mammals, fishes,

birds, annelids,

insects, reptiles)

Whole fish, raw blood, head, bile, belly, fats, brain, flesh, eyes.

Gall bladder, flesh, fat, whole body, brain scales, bone, skull bone, hand, front foot, urine, fur, blood, teeth, tongue.

Insects: Honey, whole body, hind legs. Annelids: Live leech.

Amphibians: Hind legs, skin, whole body, flesh Reptiles: Fat, whole body, blood,

heart, eggs.

Birds: Feathers, flesh, blood, fat, excreta. Mammals: Milk, urine, fat, dung, penis, bile, testicle, liver, droppings, blood.

Meat, urine, skin, alimentary canal, dung, oil, whole insect, honey, whole body, whole fish, blood. (bees), live leech, hemolymph.

Common day-to-day disorders, general weakness, body pain,

fever, asthma, allergies, diarrhea, stomach ailments, cough,

cold, dermal conditions, hemorrhoids, diabetes, burns, jaundice

liver problem, earache, malaria, epilepsy, tuberculosis, cancer,

venomous snake bites. malaria, jaundice, tuberculosis, asthma, cancer, skin disease,
Body pain, carbuncle, diabetes, obesity.

Corn, eye disease, jaundice, itch, tuberculosis, joint pain, fever, Hanse and Teron infections, urinary problems, rheumatic pain, chest pain,

Depression, anemia, kala-azar, constant spitting, weakness after delivery, night blindness, smallpox, wounds, dysentery,

common cold, rheumatism, arthritis, stomach ache, corn, testicle swelling, malaria.

Diabetes, snake bite, seizure, sprain, piles, burn, jaundice, impotency, allergy, rheumatic pain, tuberculosis, arthritis, gal stone, joint pain, malaria, dizziness, hernia, epilepsy, mumps toothache, food poisoning, hair care, blood pressure.

Cough, flu, asthma, diuretic, baldness, lung infection, throat inflammation, anti-cancer, warts, rabies, arthritis, urinary trac problems, wounds, tongue blister, piles, joint pain, leprosy, stammering, paralysis, typhoid, toothache, blood pressure, breathing problem, nasal congestion, whooping cough,

rheumatism, dysentery, tumors, bronchitis, anemia, eczema, conjunctivitis.

Diarrhea, blood pressure, dysentery, bone fracture, asthma, jaundice, chickenpox, liver disease, tonsil, body ache, leucorrhea, skin disease, female infertility, joint pain, blood cancer, pneumonia, cough, burn, piles, skin disease, abdomina pain, polio, dysmenorrhoea, tuberculosis.
Kalita et al. (2005)

Jugli et al. (2019)

Teronpi et al.

Betlu (2013)

Verma et al.

Borah and Prasad (2016) 
Ahom, Chutia,

Koch-Rajbonshi,

Kalita, tea tribes

(Adivasis).

Different ethnic

groups of Manipur

Meitei, Meitei

Pangals, Chothe,

Kabui,

Kom

Rongmei

Mizoram

Mizo

Mizo fishes, reptiles,

annelids,

amphibians,

gastropods)

33

flesh, fat, brain, bone, leg, milk, urine,

meat, intestine, fur.

21

(fishes)

Whole body, liver, bile, eye, operculum flesh, body oil, barbels.

26

mammals, birds,

reptiles,

amphibians,

mollusks, insects)

bone marrow, fat, stomach, hand/palm,

penis, hair, whole body, leg, milk.

Birds: Fat, whole bodies, bone, flesh.

Reptile: Body and fat.

Amphibian: Body.

Mollusc: Whole body

Insect: Whole body.

13 Whole body, fat/oil, bile, milk (tigress),

(mammals, fetus (pregnant deer), live fish, whole

annelids, leech, insect intestine.

arthropods, fishes)

56

Bones, ribs, hair, meat, blood, brain, bone

marrow, bile, male organ, fatty oil, milk,

invertebrates) scrotum, urine, tongue, tooth, stomach,

intestine, toes, feathers, quill, fluids from neck.

Fat, feathers, hair, bile, blood, urine, skull, fatty oil, meat, bone, skin, milk, liver, horn, tongue, intestine, rectum, male organ,

brain, ribs.
Asthma, otorrhoea, cancer, pain, sinus, epistapix, fever,

eyesight, pneumonia, vocal cord infection, piles, impotency,

bone fracture, gastric ulcer, wounds, anemia, blood pressure,

pox, snake bite, skin disease, tonsil, rabies, chronic dysentery,

paralysis.

Asthma, diabetes, tuberculosis, urine problems, antidote in

snake bites, stomach disorders, eye problems, jaundice, liver

disorders, body ache, wounds, anemia, common cold, smallpox,

diarrhea, malaria, rheumatic pain, arthritis, skin disease, piles,

hair care, and magico-religious purposes.

Night blindness, chronic fever, piles, meningitis, constipation, deworming, ripening/swelling of boils, vitamins and general

body tonic, anemia, malnutrition, post-delivery diet, lactation,

tuberculosis, blood purifier, arthritis, cracked heels, night

blindness, scurvy, food poisoning, brain improvement, kwashiorkor,

dysentery, vaginal problems, ringworm, plague, ulcer.

Tuberculosis, stomach disorder, stone case, alcoholic addict, wounds, injuries, sprains, cough, typhoid, boil, malaria, unconsciousness, epilepsy, burns, frequent urination,

impotency, eye pain, bone joining, white discharge, skin diseases and cancer.

Malaria, burns, breastfeeding problems, tongue blemish of infants, boils, whooping cough, rash, wounds.

Jaundice, convulsions, fractures, swellings, measles, liver ailments, tuberculosis, inflammatory glands, boils, chronic ulcers, asthma, chickenpox, bee sting, rheumatism, fever, headache, itch, pneumonia, piles, splenomegaly, diphtheria, whooping cough, weakness, otorrhoea, snake bite, night blindness, easy labor.

Cough, asthma, tuberculosis, paralysis, earache, weakness, muscular pain, malarial fever, convulsion, diabetes, arthritis, leprosy, wounds, burns, diarrhea, respiratory ailments, kidney problems, cholera, hypertension, jaundice, liver problems, etc.
Mihsill and Keshan (2017)

Borah and Prasad

Devi et al. (2015)

Chanu et al. (2016)

Ngaomei and

Singh (2016)

Lalramnghinglova (1999)

Chinlampianga et

al. (2013) 
Mizo, Bru and

Chakma

Nagaland Chakhesang

\section{Ao,}

Angami,

Sema, Sangtam,

Khiamniungan,

Yimchunger,

Chakhesang, Lotha,

Zeliang, Pochury and Rengma

Ao

\section{Sikkim Lepcha, Bhutia and Nepali (including} sub-communities)
Gall bladder, bones, brain, blood, tooth, fat, nails, liver, stomach, intestine, meat, quill, scales.

mammals,

reptiles, birds,

amphibians, fishes, mollusk, annelids, arthropods amphibians,

reptiles, annelids,

insects,

staceans)

25

(vertebrates)

(mammals, birds

reptiles,

amphibians,

fishes)

59

(mammals, birds

insects,

amphibians,

reptiles, lower

groups)
Gall bladder, penis, hair, fat, urine, blood, spine (porcupine), small intestine, stomach flesh, scale, bone marrow, feather, liver, skin, slimy mucus (fish), mollusk shell, honey from bees.

Whole body, flesh, fresh blood, fat, skin, gall bladder, bile duct, penis, urine, teeth and tusks (elephant), intestine, milk (goat), urine.

Fat, flesh, bile, tooth, intestine, bile, urine, liver, legs, milk, penis, blood, bones, skin.

,

Mammals: Gall bladder, bones, meat, teeth, horn, skin, musk gland (Himalayan Musk

Deer), scales, fur, urine, milk.

Birds: Meat.

Reptile: Molted skin (King Cobra)

Amphibian: Meat, egg.

Insects: Body, honey.

Others: Spider web, crab and snail meat, whole worm

Whole body, flesh, honey, head, casts of slough, testis, fecal matter, blood, antler, urine, meat, intestine, droppings.
Stomach ache, dysentery, diarrhea, cholera, malaria, epilepsy, vitamin, supplement, facilitate labor pain, strengthening of

bones, stunted growth in infants, to protect body from evil soul, tooth decay, high blood pressure, asthma, epilepsy, convulsion, birth control, hair care, itching, kidney problem, diabetes,

pneumonia, burns, cholera, cough.

Wounds, thorns in flesh, gestation/child delivery, burn,

swelling, stomach pain, anemia, bone fracture, gastritis,

malarial fever, urethritis, constipation, cough, typhoid, tongue blisters, earache, dysentery, chickenpox.

Antidote in snake and spider bites, asthma, stomach ache,

tuberculosis, eye problems, jaundice, liver disorders, rheumatic joint pain, anemia, weakness, burns, wounds, fractures, earache, aphrodisiac, general weakness, night blindness, impotency, chest pain, fever, pile, facilitating delivery, leukoderma, eczema, ringworm, breast pain of lactating mothers, cholera, dysentery, cataract, food poisoning.

Body pain, sprain, rheumatism, asthma, liver cirrhosis, leukoderm itch, eczema, ringworm, anti-poison, tuberculosis, paralysis, skin disease, stomach disorder, jaundice, night blindness, fracture, weakness, breast pain of lactating mothers, impotency, burn, snakebite, malaria, dysentery, kidney stones, breathing problem, earache, stammering, piles, snake bites, wounds.

Fever, liver problems, heart disease, diabetes, wounds, body ache, dysentery, asthma, rheumatism, piles, gout, joint pain, tuberculosis, epilepsy, parturition, food poisoning, constipation, ear pain, cough, cold, urinary tract infection, immunity booster, pneumonia, bone fracture, snakebite, malaria, bedwetting, burns, eye pain, nose bleed, improvement of vision, ulcers

Arthritis, conjunctivitis, weakness, rickets, asthma, cough, pneuno, urinary obstruction, hair loss, sex stimulant, wound, leprosy, male impotency, constipation, paralysis, earache, joint pain, fever, TB, ulcer, gout, burn, fracture.

Solanki et al.

Kakati and Doulo

Jamir and $\mathrm{La}$

Kakati et al.

Dhakal et al. 


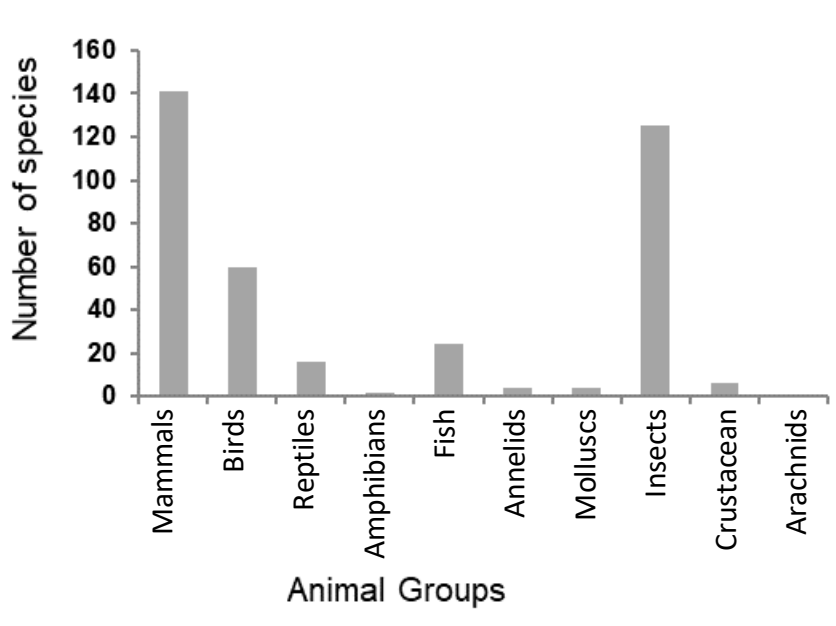

Figure 2. Type of animals used by different indigenous communities of Arunachal Pradesh, India

\section{Arunachal Pradesh}

Arunachal Pradesh is inhabited by 20 major indigenous communities (Dutta and Dutta 2005; Tynsong et al. 2020). These indigenous communities rely primarily on forest resources and follow activities such as collection of NonTimber Forest Products (NTFPs), hunting, fishing, and animal trapping for their use in ethnomedicine and food (Solanki et al. 2004; Solanki and Chutia 2009).

Research by Solanki and Chutia (2009) stated that indigenous communities, namely Nyishi, Apatani, and Monpa, use approximately a total number of 100 animal species for their ethnomedicines; $48 \%$ of which belongs to mammalian species, $28 \%$ avian species and rest belong to amphibians and reptiles. For mammals, body parts such as skin, bones, fats, gall bladder, food pipe, reproductive organ and horns are used, whereas, in case of avian species, feathers and legs are predominantly used in traditional medicine formulations. Furthermore, the use of edible insects is also prevalent among the Galo community in ethnomedicine. Dagyom and Gopi (2009) reported a total of 12 edible insects along with four unidentified species that were used for ethno-zoological purposes by Galo tribes. A research carried out by Chakravorty et al. (2011a) reported that Nyishi and Galo communities use 81 species of edible and therapeutic insects and 36 vertebrate species for treating different ailments. Use of therapeutic insects and vertebrates by Nyishis and Galos has been found effective in curing ailments in domesticated cattle (Chakravorty et al. 2011b). Chinlampianga et al. (2013) estimate that Adi community use approximately 39 animal species (terrestrial and aquatic) in their conventional healthcare practice program. Bear, deer, ant's larvae, fish, porcupine tail, lizard, squirrel, hornbill, monkey, etc. are some of the species used by the Adi community. Usage of fish species viz., Heteropneustes fossilis and Clarius batracus and the use of insects with ant's larvae by females of Adi community have been reported to cure weak people and malaria sufferers (Chinlampianga et al. 2013). Monpa community uses about 11 animals (mammals and birds) for therapeutics as well as in many rituals of healing and religion (Solanki and Chutia 2004). The children of the Monpas are made to wear bear claws around their necks in their ancestral rituals as a belief in protecting them from evil spirits and performing the sacrifice of animals such as sheep, goats, etc., with a belief that satisfying their gods will alleviate suffering and promote healing (Solanki and Jhutia 2004). Recent research by Jugli et al. (2019) ecorded the use of 20 and 55 animal species among the thnic groups of Wancho and Tangsa respectively, for therapeutics in humans and domesticated animals.

Figure 2 provides a graphic representation of the applications of animal classes by various indigenous communities of Arunachal Pradesh. The application of mammals, insects and birds is found to be the highest, while the application of other classes such as reptiles, amphibians, annelids, mollusks and crustaceans is seen to be less.

\section{Assam}

Assam is the second largest state in NE India and is home to a large number of cultural, natural as well as biological diversities (Borah and Prasad 2016). There have been numerous studies on the use of traditional plant-based medicine (Sajem and Gossai 2006; Saikia et al. 2006; Das et al. 2008; Sikdar and Dutta 2008), and mixed formulations using both plants and animals (Kalita et al. 2005; Betlu 2013) reported from the state. There are, however, very few reports on the use of animal-based medicines for treatment of ailments. Some studies relating to use of animals in traditional medicines are of Borah and Prasad (2016) on the application of 26 animal species to treat diseases like jaundice, asthma and pneumonia by local ethnic groups viz., Nath and Karbi; Borah and Prasad (2017) on extensive use of 44 species of animals for several ethno-zoological applications by indigenous communities like Ahom, Chutia, Koch-Rajbonshi, Kalita, and Tea tribes (Adivasis). Similarly, Hanse and Teron (2012), Teronpi et al. (2012), and Verma et al. (2014) also conducted a study among the Karbi community of the Karbi-Anglong District of Assam on the applicability of 14 species of animals, 14 species of ichthyofauna (fish), and 48 species of various animals respectively, for therapeutic purposes in the treatment of diseases such as piles, cancer, tuberculosis and eczema.

Analysis of reports from the state of Assam reveals that use of mammals is the highest, followed by fish, insects, birds, and reptiles (Figure 3). Application of other groups of animals like amphibians, annelids, mollusks, crustaceans and arachnids are least in use. 


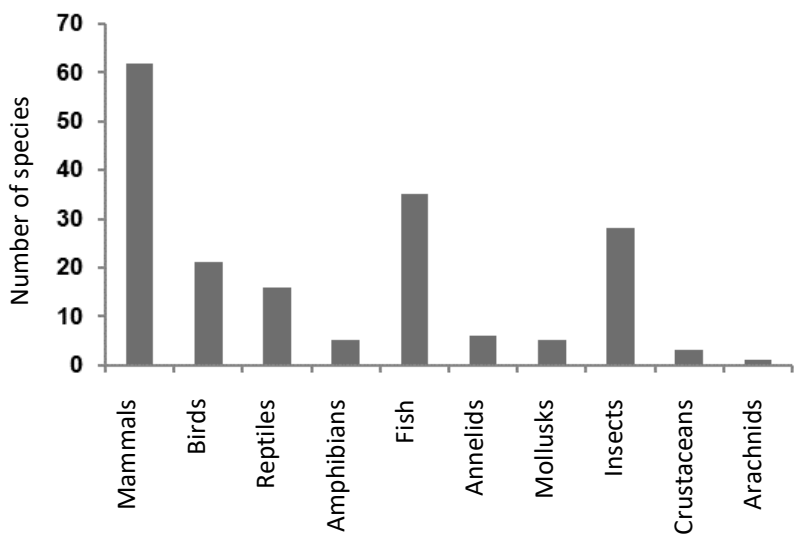

Figure 3. Type of animals used by different indigenous communities of Assam

\section{Manipur}

Manipur is an oval-shaped valley state surrounded by hills (Devi et al. 2015). The State is known for its rich and varied natural resources, and is home to many native flora and fauna species (Chanu et al. 2016). Zootherapy among several groups in Manipur has been found to be an integral part of traditional folk healthcare practices (Devi et al. 2015). Indigenous communities of Manipur are accustomed to using a large number of animal species (wild and domesticated) in zoo-therapy procedures, the activities that involve both local and oral methods (Devi et al. 2015).

Research conducted by Chanu et al. (2016) recorded that the Meitei community had used some fish species as ethnomedicine. A total of 21 species of fish belonging to 11 families and 18 genera have been primarily used in the preparation of ethnomedicine by the Meitei community (Chanu et al. 2016). Fish are eaten raw, fried, or cooked for medicinal purposes, depending on the procedure prescribed/followed. Some of the most common fish species used by the Meitei community in ethnomedicine include Aorichthys seenghala, Anguilla bengalensis, Barilius bendelisis, Catla catla, Channa orientalis, Channa striatus, Esomus danrica and Hilsha ilisha. Meitei Folk Healers use liver, eye, bile, operculum, fish oil, barbels, and sometimes whole body of the fish (Chanu et al. 2016).

Another important study on animal-based ethnomedicine in Manipur had reported that a total of 33 animals are used in traditional zoo-therapy treatments by the traditional folk healers of Manipur; comprising of five invertebrates and 28 vertebrate species for treatment of 35 different ailments (Devi et al. 2015). It is stated that there are four different types of traditional zoo-therapies employed by Manipur's traditional folk healers, i.e., food, medicine, magico-religious, and faith healing, in which animals are either used completely or in parts depending on their needs. Similarly, Ngaomei and Singh (2016) reported that the Rongmei community of Manipur used a total of 26 animal species consisting of 14 mammals, 3 avian species, 3 reptiles, 2 amphibians, 1 mollusk, and 4 insect species to treat ailments such as rheumatic pain, typhoid and stomach disorders. The Rongmei community usually uses parts of

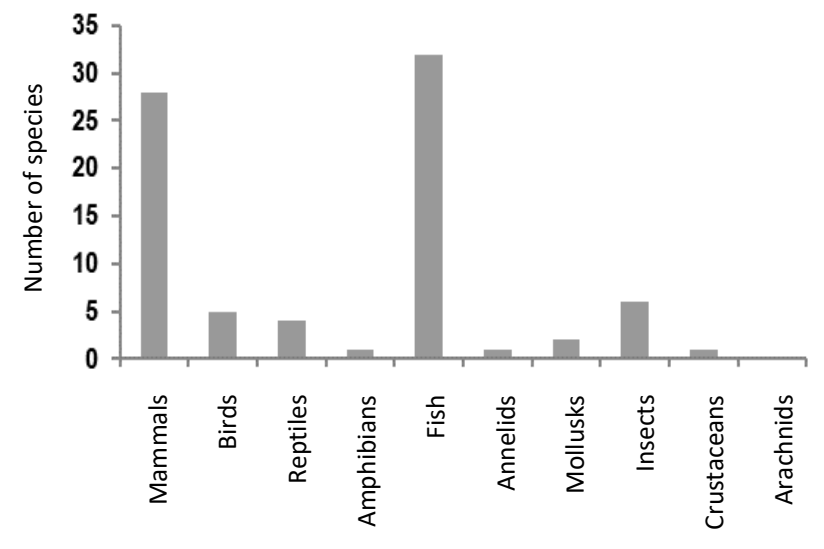

Figure 4. Type of animals used by different indigenous communities of Manipur

the body such as flesh, bones, bone marrow, urine, bile, tongue, fat, stomach, hand, palms, hair, and whole body in traditional medicine formulations.

It is observed that application of fish species in traditional medicines is highly prevalent in Manipur, followed by the use of mammals, insects, birds and reptiles (Figure 4). Use of amphibians, annelids, mollusks, and crustaceans is also prevalent.

\section{Meghalaya}

In Meghalaya, indigenous communities have existed in profound and intense communion with nature from time immemorial (Mihsill and Keshan 2017). The Khasi, Jaintia, and Garo are the three primary indigenous communities in Meghalaya, which together constitute $86 \%$ of the overall population of the state (Tiwari et al. 2010). There have been numerous studies on the use of traditional plant-based medicine (Laloo et al. 2006; Tynsong et al. 2006; Sawian et al. 2007; Hynniewta and Kumar 2008) while reports on the use of traditional medicine based on animals in Meghalaya are extremely limited. Research conducted by Turnia and Prasad (2017) confirmed that the Khasi community used 13 animal-based medicine to treat ailments such as asthma, anemia, diarrhea and regular cough, cold and fever. Mihsill and Keshan (2017) documented the use of animals and animal products in traditional cure practices by the Khasis. Mihsill and Keshan (2017) reported that Khasi community believe that malaria can be cured by consuming hill mole (known as 'kyndat lyndang' in Khasi dialect) or cow bile, tigress milk mixed with mud in healing burns; sun-dried deer fetus to cure 'suhsynria' in khasi dialect (a condition of disease prevalent in breastfeeding mothers), use of catfish (Channa striatus) to treat a condition similar to leukoderma in infants and use of leeches to suck blood from pus boils.

It is observed that in Meghalaya, mammals are mainly used in traditional medicine followed by insects. However, use of other animal groups like birds, amphibians, mollusks, crustaceans, etc., for zoo-therapeutic applications is not reported (Figure 5). 


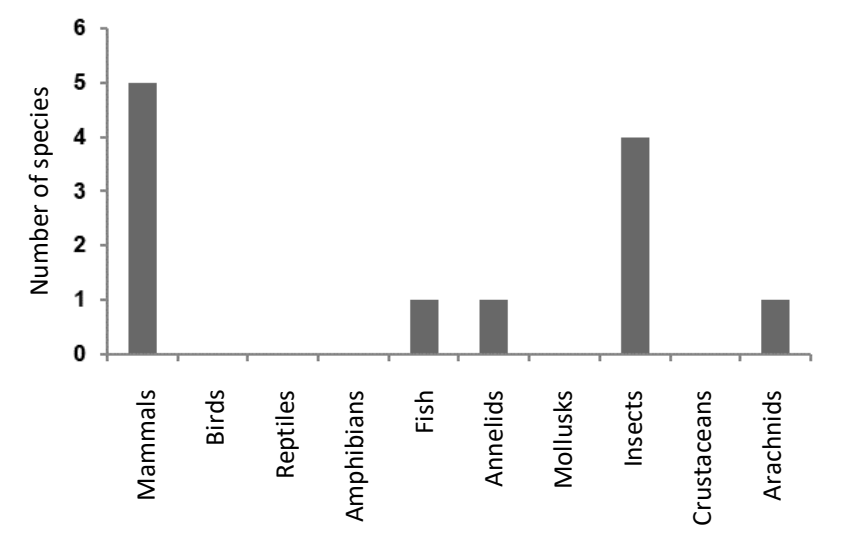

Figure 5. Type of animals used by different indigenous communities of Meghalaya

\section{Mizoram}

Mizoram is a hilly state located in the lower corner of the NE region, traversing many ranges of hill slopes; and less scattered plains and is inhabited primarily by two distinct indigenous communities i.e., Chakma and Mara; besides other communities such as Lai, Paite, and Hmar (Chinlampianga et al. 2013). Traditional health care systems using animals were well defined and documented in Mizoram (Harit 2001). Mizoram's ground-breaking research on ethno-zoological traditional medicine emphasized the use of at least ten animal species for the treatment of asthma and respiratory disorders, including reports for multiple ailments of a total of 56 animal species (Lalramnghinglova 1999). A study conducted by Chinlampianga et al. (2013) in the Zomi-Paite community revealed that a total of 48 species of fauna consisting of mammals, birds, reptiles, arthropods, amphibians, annelids, insects, and fish are used for diseases like asthma, arthritis, leprosy, malaria, wound, respiratory, kidney, gynecological, cholera, tuberculosis, diabetes, hypertension, and jaundice. Animal body parts or organs used for the practice of ethnomedicine include fat, feather, hair, bile, blood, meat, bone, skin, milk, and liver; either in cooked/boiled/roasted form (Chinlampianga et al. 2013). Solanki et al. (2016) stated that the Mizo, Bru, and Chakma communities used animals for medicinal applications and approximately nine mammalian species, three reptiles, and one bird species have been commonly used for medicinal purposes, mainly utilizing body parts such as gall bladder, bones, brain, blood, hair, skin, nails, liver, stomach, and intestines.

Existing literature on zoo-therapeutic applications in Mizoram shows that use of mammals had been the largest, followed by use of birds, reptiles and insects. Applications of other animal groups such as amphibians, reptiles, annelids, mollusks, crustaceans, and arachnids are also prevalent but at comparatively smaller frequencies (Figure 6).

\section{Nagaland}

Nagaland state borders Arunachal Pradesh, Assam, and Manipur; and is made up of plains and hilly regions. Nagaland is inhabited by several indigenous communities like Ao, Angami, Lotha, Phom, Chang, Sangtam,

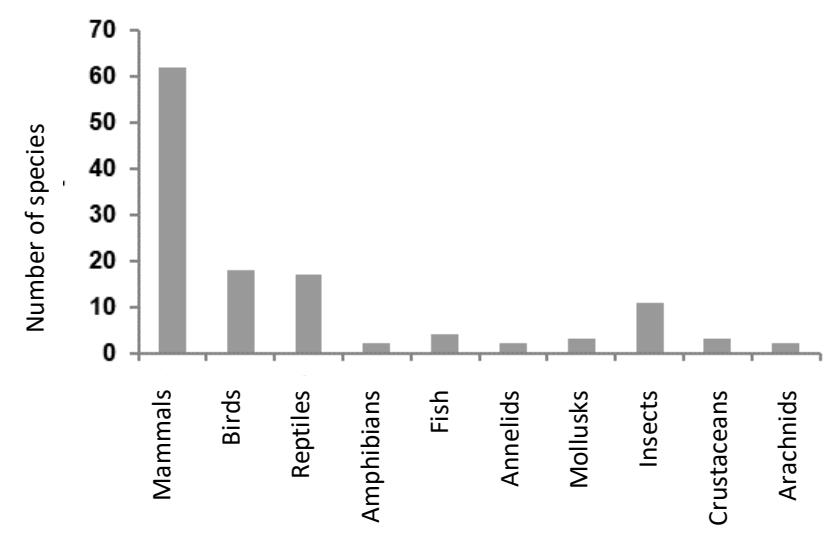

Figure 6. Type of animals used by different indigenous communities of Mizoram

Chakhesang, Zeliang, Rengma, Yumchunger, Khiamniungan, Konyak, Sema, Pochury and various subgroups (Zhimomi 2004). Research conducted by Jamir and Lal (2005) on ethnozoological knowledge reported a total of 26 animal species used by 11 indigenous communities in Nagaland for zoo-therapeutic remedies. Cat, deer, bear, dog, elephant, goat, flying squirrel, jackal, monkey, frog, python, cobra, crow, pheasant, pigeon, peacock, earthworm, apple snail, cockroach, crab, scorpion and eel are some of the animals used for traditional medicine. Organ/body parts used for medical practice include whole meat, gall bladder; extracts from the bile ducts, fresh blood, and whole body consumed raw/cooked, skin and male organ.

Kakati and Doulo (2002) recorded animal use in traditional medicines among the Chakhesang community of Nagaland, which employed 23 animal species. Among the Ao community, comprehensive research on ethnozoological knowledge was conducted by Kakati et al. (2006), who recorded that people relied on zoo-therapeutic medicines to treat diseases such as body pain, rheumatism, asthma, liver disorders, tuberculosis, night blindness, bone fractures, malaria, dysentery, kidney problems, and respiratory disease. Kakati et al. (2006) recorded that a total of 25 different species of vertebrates are used by Ao community which include mammals, aves, reptiles, amphibians, and fish. Traditional healers of Ao community use body parts like fats, meat, bile, teeth, intestine, urine, liver, legs, milk, blood, bones, and skin.

It is noted that indigenous communities of Nagaland primarily use mammals in their traditional medicine accompanied in their various formulations, followed by birds, reptiles, amphibians and insects. Other animal groups such as fish, annelids, mollusks, crustaceans, and arachnids also find their uses in traditional medicine of Nagaland (Figure 7).

\section{Sikkim}

Sikkim is located in the foothills of the Himalayas, inhabited by indigenous communities like Lepcha, Bhutia and Nepali following diverse cultures and traditions (Dhakal et al. 2019). Literature survey on the use of 
traditional medicine in Sikkim revealed that the state relies heavily on the state's flora, which has a rich and large range of natural resources (Dhakal et al. 2019). Knowledge regarding the use of faunal medicine as part of traditional folklore is fairly scanty and fragmentary. Dhakal et al. (2019) conducted a comprehensive survey of traditional communities and reported that males of such communities were dominant in traditional medicine usage compared to females; and are mostly people with lower annual incomes and practice as a part-time livelihood. Dhakal et al. (2019) recorded that 59 animal species were used in ethnozoological practices, $71 \%$ of which were used in zootherapy, while the remaining $39 \%$ were recorded to be used in various religious or shamanic activities. Of the 59 animals, 34 were mammals, 13 bird species, and rest consisted of insects, amphibians, reptiles, mollusks, etc.; suggesting mammals as the dominant group used in traditional medicine (Figure 8).

\section{Tripura}

Tripura is a small hilly state, inhabited by 19 indigenous communities (Das 2015). Studies on traditional medicine using flora and fauna are extremely limited in Tripura, with few recorded studies on the use of ethnomedicinal plants (Das et al. 2009; Sen et al. 2011; Sharma et al. 2014; Debbarma et al. 2017), and scarce details on the use of ethnomedicine based on animals. A study on use of ethnomedicine based on animals by Das (2015) provided a detailed report on the applications of ethnozoological medicine practiced by the Tripuri, Jamatia, and Reang communities of Tripura. Das (2015) recorded the use of 25 animal species being used for the treatment of asthma, paralysis, cough, fever and wound healing. Many animals used in ethnomedicine include goat (for tuberculosis, ulcer and gout treatment), apple snail (conjunctivitis and rickets), pigs (fractures, burns and wounds), while animals such as cows and fish have been documented to be in lesser uses as compared to other animals (Das 2015). Existing literature on zoo-therapeutic applications in Tripura reveals that use of mammals is the highest, followed by use of insects, birds, crustaceans, and fish (Figure 9).

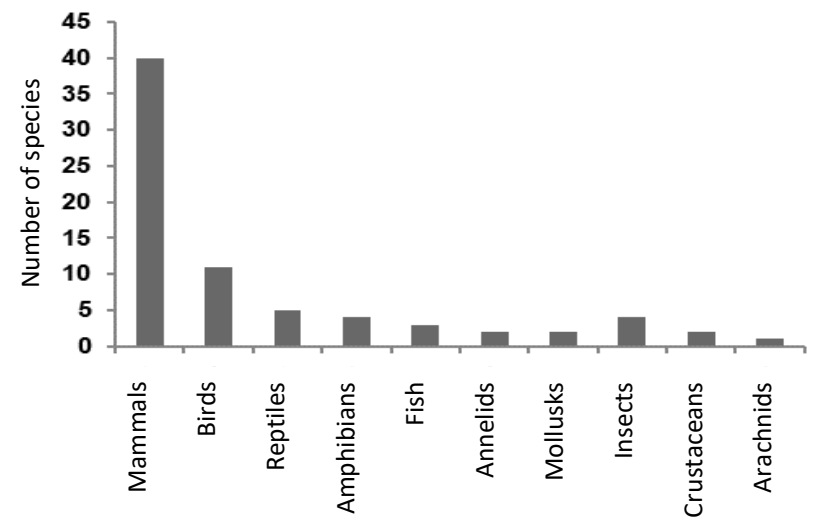

Figure 7. Type of animals used by different indigenous communities of Nagaland

\section{Animals used in the treatment of various diseases}

Based on our comprehensive literature survey, we could assess that malaria, tuberculosis, wounds, cough and cold, burns, dysentery, jaundice, stomach disorders, rheumatism, asthma, liver problems, joint pain, fever, fatigue, women's issues, fractures, animal/insect bites, anemia, male impotence and diabetes are the 20 most common diseases which are reported to be cured with the application of ethno-zoological medicines. Details of the types of animals used to treat these diseases and the indigenous communities involved are provided in Table 3.

In the ethnozoological applications among communities of NE India, mammals, fish, reptiles, annelids, amphibians, mollusks, insects, birds, crustaceans, mollusks, arachnids, etc., are widely used species types. Analysis of the IUCN Red List of Endangered Species (IUCN 2020) shows that 58 species are classified as Least Concern (LC), 21 species are classified as Vulnerable (VU), 9 species are classified as Endangered (EN), 7 species are classified as Near Threatened (NT), 3 species are classified as Critically Endangered (CR), 1 species is classified as Data Deficient (DD). Conservation status of these animal species as per IUCN (2020) is provided in Table 4.

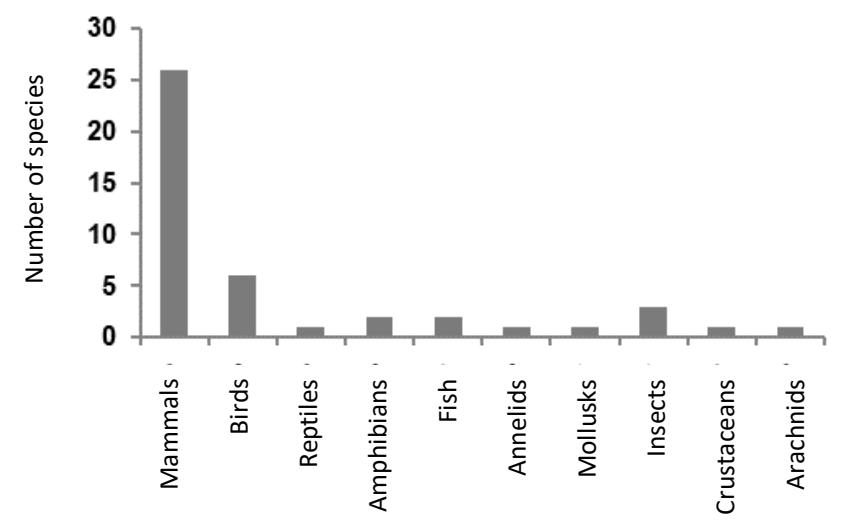

Figure 8. Type of animals used by different indigenous communities of Sikkim

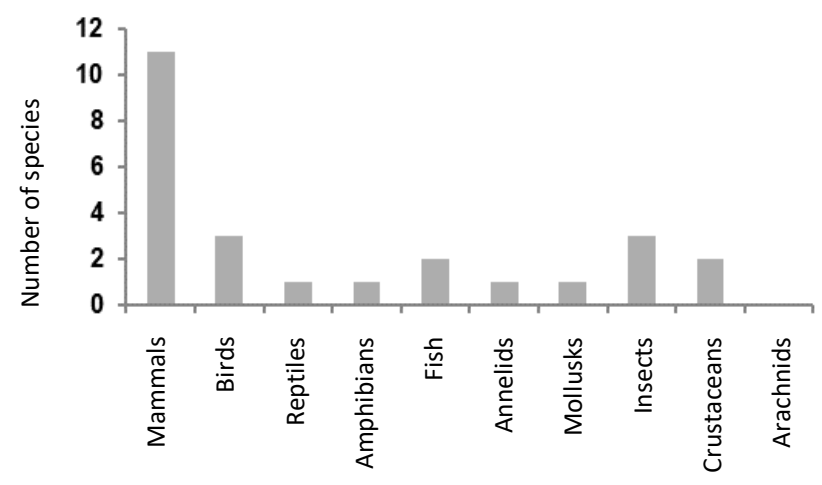

Figure 9. Type of animals used by different indigenous communities of Tripura 
Table 3. Details and number of animals used in the ethno-zoological treatment 20 most common ailments/diseases

\begin{tabular}{ll} 
Disease & Animals used \\
\hline Malaria & Channa punctatus (Snake head fish), Anabus testudineus \\
(37 species) & (Fish), Solenopsis sp. (Red ant), Aspongopus najus (Tari \\
& insect), Cimex lactularis (Bed bug), Hystrix indica (Indian \\
porcupine), Maccaca assamensis (Assamese Macaque), & Pheritima sp. (Earthworm), Tehanochelys trijuga (Turtle), \\
& Varanus bengalensis (Monitor Lizard), Viper ruselli (Viper), \\
& Haliaeetus sp. (Eagle), Dicrurus sp. (Drongo), Buceros \\
& bicornis (Great Hornbill), Megalaima sp. (Barbet), Panthera \\
& tigris (Tiger), Manis sp. (Pangolin), Pteropus sp. (Flying fox), \\
& Chiroptera sp. (Bat), Bothroponera rufipes (Black ant), \\
& Moschus sp. (Musk Deer), Ursus thibetanus (Black bear), \\
& Panthera pardus (Leopard), Trachypithecus pileatus (Capped \\
& langur), Macaca mulatta (Rhesus monkey), Bunopithecus \\
& hoollock (Hoolock gibbon), Corvus culminatus (Jungle Crow), \\
& Bos sp. (Mithun), Vulpes bengalensis (Fox), Testudo sp. \\
& (Tortoise), Mastacembelus armatus (Spiny eel), Canis aureus \\
& (Golden jackal), Nycticebus coucang (Slow loris), Talpa sp. \\
& (Hill mole), Python molurus (Python), Cancer pararus (Crab) \\
& and Felis silvestris (Wild cat).
\end{tabular}

Tuberculosis Pila globusa (Apple Snail), Periplaneta americana

(21 species) (Cockroach), Moschus moschiferus (Musk deer), Talpa sp.

(Mole), Vulpes bengalensis (Fox), Hystrix sp. (Porcupine)

Selenarctos thibetanus (Himalayan black bear), Macaca

assamensis (Assamese macaque), Hoolock leuconedys (Eastern

Hoolock Gibbon), Python molurus (Indian python),

Amphipnous cuchia (Cuchia), Capra hircus (Goat), Manis

crassicaudata (Indian pangolin), Channa punctatus (Spotted

snakehead fish), Tachypodoiulus niger (Black millipede),

Canis familiaris (Dog), Macaca mulatta (Rhesus monkey),

Naurey musa (Mongoose), Scylla sp. (Mud crabs)

Eutropiichthys vacha (Fish) and Canis aureus (Wild fox).

\section{Indigenous communities and their state}

Adi, Apatani, Galo, Monpa, Nyishi, Tangsa and Wancho

of Arunachal Pradesh; Biate and Karbi of Assam;

Rongmei and other groups of Manipur; Khasis of

Meghalaya; Mizo, Bru and Chakma of Mizoram; Ao and

Chakhesang of Nagaland; Lepcha, Bhutia and Nepali of

Sikkim.

Apatani, Nyishi, Monpa, Galo and Tangsa of Arunacha

Pradesh; Karbi, Biate and Nath of Assam; Meitei, Pangals,

Chothe, Kabui, Kom (Moirang-maninghao), Rongmei and others of Manipur; Mizo of Mizoram; Ao, Angami, Sema,

Sangtam, Khiamniungan, Yimchunger, Chakhesang,

Lotha, Zeliang, Pochury and Rengma of Nagaland;

Lepcha, Bhutia and Nepali of Sikkim; Tripuri, Jamatia and Reang of Tripura.
Literature

Solanki and Chutia (2004); Kakati et al. (2006); Chakravorty et al. (2011 a); Chinlampianga et al. (2013); Betlu (2013); Verma et al. (2014); Devi et al. (2015); Ngaomei and Singh (2016); Solanki et al. (2016); Mihsill and Keshan (2017); Dhakal et al. (2019); Jugli et al. (2019).
Jamir and Lal (2005); Kakati et al. (2006); Solanki and Chutia (2009); Chakravorty et al. (2011b); Hanse and Teron (2012); Betlu (2013); Verma et al. (2014); Das (2015); Devi et al. (2015); Borah and Prasad (2016); Chanu et al. (2016); Ngaomei and Singh (2016); Dhakal et al. (2019); Jugli et al. (2019). 


\begin{tabular}{ll}
\hline Wounds & Mastacembelus armatus (Eel fish), Chaca chaca (Fish), \\
(33 species) & Python molurus (Python), Naja naja (Cobra), Spizaetus sp. \\
& (Eagle), Dicrurus sp. (Drongo), Strigiformes sp. (Owl), \\
& Buceros sp. (Hornbill), Megalaima sp. (Barbet), Panthera \\
& tigris, Bos frontalis, Hystrix brachyuran (Porcupine), Ursus \\
& thibetanus (Himalayan Black Bear), Manis sp. (Pangolin), \\
& Pteropus sp. (Flying fox), Chiroptera sp. (Bat), Bothroponera \\
& rufipes, Amblyceps sp. (Fish), Rana sp. (Frog), Panthera \\
& pardus, Mantis religiosa (Praying mantis), Clarias batrachus \\
& (Magur fish), Heteropneustes fossilis (Singing catfish), Human \\
& urine, Caurausius sp. (Stick insect), Araneae sp. (Spiders), \\
& Canis aureus (Jackal), Sus scrofa (Pig), Lepus nigricollis \\
& (Indian Hare), Tetragonula iridipennis (Stingless bee), \\
& Rucervus unicolor (Sambar Deer), Rhizomys sumatrensi \\
& (Bamboo rat) and Pila sp. (Snail).
\end{tabular}

Cough and cold

(31 species)

Apis sp. (Honey bee), Polistes sp. (Wasp), Vespa orientalis (Potter wasp), Melursus ursinus (Sloth bear), Moschus sp.

Ursus thibetanus (Asiatic Black Bear), Anthracoceros albirostris (Pied hornbill), Python molurus, Cynopterus sphinx Equus asinus (Donkey), Sciurus caroliniensis (Squirrel), Mus musculus (House mouse), Periplaneta americana, Calotes versicolor (Common garn lizard), Canis aureus, Helarctos malayanus (Malayan sun bear), Buceros sp. (Great hornbill), Corvus sp. (Jungle crow), Hystrix sp., Lepus nigricollis, Bos sp. (Cattle), Sus domesticus (Pig), Nanorana liebigii (Frog), Tetragonula iridipennis, Capra aegagrus (Goat), Felis silvestris, Macaca $\mathrm{sp}$. (Monkey), Cancer pararus (Crab), and Podisus sp. (Plant bug).

Burns

(30 species)

Anguilla sp. (Eel), Bagarius sp. (Gangetic goonch), Amblyceps sp. (Catfish), Spilornis cheela (Eagle), Ursus thibetanus, (Bat), Macrocheraia sp. (Giant red bug), Puntius sp. (Fish), Lepcha, Bhutia and Nepali of Sikkim; Tripuri, Jamatia

Melursus ursinus, Panthera tigris, Neofelis nebulosa (Clouded leopard), Pteromys sp. (Flying Squirrel), Capra sp., Nycticebus sp. (Slow loris), Human urine, Buceros sp., Gallus domesticus (Chicken), M. armatus (Spiny eel fish), Python reticulates (Reticulated python), Sartoriana sp. (Red freshwater crab), Varanus bengalensis, Gallus sp. (Jungle Fowl), Lutrogale perspicillata (Smooth-coated otter), Metaphire houletti (Earthworm), Apis sp. Canis sp. (Dog), Manis sp., Sus scrofa (Pig), Ovis aries (Sheep), Lymnonecties sp. (Frog), Cervus sp. (Deer), Hystrix sp., and Pila sp. (Snail).
Apatani, Nyishi, Monpa, and Galo of Arunachal Pradesh; Ahom, Chutia, Koch-Rajbonshi, Kalita and Adivasis and Karbis of Assam; Rongmei and other groups of Manipur; Khasi of Meghalaya; Mizo of Mizoram; Ao, Angami,

Sema, Sangtam, Khiamniungan, Yimchunger,

Chakhesang, Lotha, Zeliang, Pochury and Rengma of

Nagaland; Lepcha, Bhutia and Nepali of Sikkim; Tripuri, Jamatia and Reang of Tripura.

Nyishi, Galo, Apatani, Monpa, Tangsa and Wancho of Arunachal Pradesh; Nath and Karbi of Assam; Rongmei and other groups of Manipur; Khasi of Meghalaya; Mizo, Bru and Chakma of Mizoram; Chakhesang of Nagaland; and Reang of Tripura.

Kakati and Doulo (2002); Kakati et al. (2006); Solanki and Chutia (2009); Chakravorty et al. (2011a); Teronpi et al. (2012); Verma et al. (2014); Das (2015); Ngaomei and Singh (2016); Borah and Prasad (2017); Mihsill and Keshan (2017); Dhakal et al. (2019).

Lalramnghinglova (1999); Kakati and Doul (2002); Solanki et al. (2004); Teronpi et al. (2012); Verma et al. (2014); Das (2015); Devi et al. (2015); Borah and Prasad (2016);

Ngaomei and Singh (2016); Mihsill and Keshan (2017); Jugli et al. (2019); Dhakal et al. (2019).

Nyishi, Galo, Tangsa and Wancho of Arunachal Pradesh; Biate, Nath and Karbi of Assam; Rongmei, of Manipur;

Kakati and Doulo (2002); Jamir and Lal (2005); Kakati et al. (2006); Chakravorty et al. Khasi of Meghalaya; Mizo, Bru and Chakma of Mizoram; Ao, Angami, Sema, Sangtam, Khiamniungan, Yimchunger, Chakhesang, Lotha, Zeliang, Pochury and Rengma of Nagaland; Lepcha, Bhutia and Nepali of Sikkim; Tripuri, Jamatia and Reang of Tripura. (2011b); Betlu (2013); Das (2015); Borah and

Prasad (2016); Ngaomei and Singh (2016);

Solanki et al. (2016); Mihsill and Keshan

(2017); Dhakal et al. (2019); Jugli et al. (2019). 


\begin{tabular}{ll}
\hline Dysentery & Acheta sp. (Cricket), Dinocras cephalotes (Stone fly), \\
(32 species) & Ephemera dancia (May fly), Philopotamus montanus (Caddis \\
& fly), Musca domestica (Housefly), Gallus gallus, Dicrurus sp. \\
& (Drongo), Tyto alba (Brown owl), Buceros sp. (Hornbill), \\
& Megalaima sp. (Barbet), Panthera tigris, Moschus moschiferus \\
& (Musk deer), Macaca assamensis, Trachypithichus pileatus \\
& (Capped langur), Bunopithicus hoolock (Hoolock gibbon), \\
& Ursus thibetanus (Himalayan Black Bear), Manis sp. \\
& (Pangolin), Pteropus giganteus (Flying fox), Cynopterus \\
& sphinx (Bat), Bothroponera rufipes (Black ant), Oecophylla \\
& smaragdina (Red tree ant), Hystrix sp., Panthera pardus, \\
& Python sp., Cervus sp. (Musk Deer), Bos indicus (Cow), \\
& Channa gachua (Fish), Varanus bengalensis, Pseudois nayaur \\
& (Himalayan blue sheep), Hemitragus jemlahicus (Himalayan
\end{tabular}

Jaundice

(24 species)

Capricornis sumtraensis (Serow), Naemorhedus goral (Himalayan Goral), Pseudois nayaur (Bharal), Budorcas taxicolor (Takin), Macaca assamensis Trachypithichus pileatus, Bunopithicus hoolock, Ursus thibetanus, Manis pentadactyla, Pteropus giganteus (Flying fox), Cynopterus sphinx (Bat), Panthera tigris, Melursus ursinus, Hystrix sp., Varanus bengalensis, Rhinoceros unicornis (one-horned Rhino), Bos indicus (Cow), Amphipnous cuchia (Eel), Ovis aries (Sheep), Corvus macrorhynchos (Jungle crow), Lymnaea sp. (Water snail), Xestina sp. (Land snail), Capra sp., and Cancer pararus (Crab).

Stomach

ailments

(29 species)

Pila sp., Cancer pararus, Polistes herbraeus (Wasp), Dinocras cephalotes (Stone fly), Ephemera dancia (May fly),

Philopotamus montanus (Caddis fly), Varanus bengalensis, Geoemyda mouhati (Tortoise), Ursus thibetanus, Manis sp., Apis sp., Oecophylla smaragdina (Red tree ant), Semiplotus sp., (Fish), Labeo rohita, Bagarius sp., Corvus splendens, Capra sp., Moschus sp., Melursus ursinus, Python molursus, Geochelone emys (Eastern hill tortoise), Hoolock hoolock,

Macaca sp., Antilocapra americana (Antelope), Hystrix sp.,

Callosciurus (Oriental tree squirrel), Archispirostreptus gigas (Millipede), Human urine and Sus crisatus (Wild boar).
Apatani, Nyishi, Galo and Monpa of Arunachal Pradesh;

Ahom, Chutia, Koch-Rajbonshi, Kalita, Adivasis, Nath,

Karbi and Dimasa of Assam; Meitei, Meitei Pangals,

Chothe (Lamlanghupi), Kabui (Nambol), Kom (Moirang-

maninghao) of Manipur; Mizo, Bru and Chakma of

Mizoram; Ao, Angami, Sema, Sangtam, Khiamniungan,

Yimchunger, Chakhesang, Lotha, Zeliang, Pochury and

Rengma of Nagaland; Lepcha, Bhutia and Nepali of

Sikkim;

Apatani, Nyishi, Galo, Monpa and Tangsa of Arunachal Pradesh; Nath, Karbi and Biate of Assam; Mizo of

Mizoram; Ethnic groups of Manipur; Ao, Angami, Sema Sangtam, Khiamniungan, Yimchunger, Chakhesang,

Lotha, Zeliang, Pochury and Rengma of Nagaland.

Apatani, Nyishi, Galo, Monpa, Tangsa and Wancho of Arunachal Pradesh; Karbi and Dimasa of Assam; Rongmei of Manipur; Mizo, Bru and Chakma of Mizoram; Ao, Angami, Sema, Sangtam, Khiamniungan, Yimchunger, Chakhesang, Lotha, Zeliang, Pochury and Rengma of Nagaland.
Kakati and Doulo (2002); Jamir and Lal

(2005); Kakati et al. (2006); Chakravorty et al.

(2011a); Chakravorty et al. (2011b); Teronpi et

al. (2012); Verma et al. (2014); Borah and

Prasad (2016); Chanu et al. (2016); Solanki et

al. (2017); Dhakal et al. (2019).
Lalramnghinglova (1999); Jamir and Lal (2005); Kakati et al. (2006); Solanki and Chutia (2009); Hanse and Teron (2012); Betlu (2013); Verma et al. (2014); Devi et al. (2015); Jugli et al. (2019).
Lalramnghinglova (1999); Jamir and Lal (2005); Kakati et al. (2006); Hanse and Teron (2012); Teronpi et al. (2012); Devi et al.

(2015); Ngaomei and Singh, (2016); Solanki et al. (2016); Jugli et al. (2019). 


\begin{tabular}{|c|c|}
\hline $\begin{array}{l}\text { Rheumatism } \\
\text { (33 species) }\end{array}$ & $\begin{array}{l}\text { Varanus bengalensis, Naja naja (Cobra), Haliaeetus sp. } \\
\text { (Eagle), Megalaima sp. (Barbet), Pardofelis sp. (Marbled cat), } \\
\text { Civettictis sp. (Civet), Martes flavigula (Yellow-throated } \\
\text { marten), Mustela sp. (Weasel), Herpestes sp. (Mongoose), } \\
\text { Lutrinae sp. (Otter), Moschus moschiferus, Hystrix } \\
\text { brachyuran, Panthera tigris, Panthera paradus, Cervulus } \\
\text { muntjac (Barking deer), Cryptozona sp. (Snail), Hoolock } \\
\text { hoolock, Puntius sp. (Fish), Crotalus durissus (Neotropical } \\
\text { rattle snake), Dusicyon sp. (Fox), Ovis aries, Arctonyx collaris } \\
\text { (Hog badger), Buceros sp. (Wheated hornbill), Bagarius sp., } \\
\text { Sus scrofa, Anguilla bengalensis, Salenarctos sp., Palamnaeus } \\
\text { swammerdami (Scorpion), Python reticulates, Lymnonecties } \\
\text { limnorcharis (Frog), Centropus sinensis (Greater Coucal), } \\
\text { Bubalus arnee (Wild water Buffalo), and Corvus splendens. }\end{array}$ \\
\hline
\end{tabular}

Asthma (37 species)

Pila sp., Periplaneta americana, Acheta sp., Mastacembelus armatus, Monopterus cuchia (Eel fish), Varanus bengalensis, Geoemyda mouhati (Tortoise), Capricornis sumtraensis (Serow), Naemorhedus goral (Goral), Pseudois nayaur. Budorcas taxicolor, Hoolock leuconedys, Anthracoceros albirostris (Pied hornbill), Cynopterus sp. (Bat), Polypedates leucomystax (Common tree frog), Amblypharyngodon mola (Indian carplet fish), Chaca chaca, Herpestes edwardsii,

Sciurus caroliniensis (Squirrel), Apis sp., Pseudacanthotermes sp. (Termite), Talpa sp., Bos gaurus (Indian Bison), Calotes versicolor, Canis familiaris, Centropus sinensis, Hystrix indica, Picus canus (Black napped green woodpecker), Viverricula indica (Small Indian Civet), Carcinus sp. Pteropus sp. (Flying fox), Ursus thibetanus, Lumbricus sp. (Earthworm), Capra sp., Petaurista petaurista (Red Giant Flying squirrel), Gallus sonnerati (Jungle fowl), and Columba livia (Pigeon). $\begin{array}{ll}\text { Liver ailments } & \text { Vulpes bengalensis (Fox), Rhizomys pruinosus (Hoary bamboo } \\ \text { (14 species) } & \text { rat), Hystrix sp., Cynopterus sphinx (Bat), Hoolock leuconedys }\end{array}$ (14 species) (Hoolock gibbon), Bos indicus (Cow), Wallago attu (Fish), Cancer sp. (Crab), Lymnaea sp. (Water snail), Melursus ursinus (Sloth bear), Rhinoceros unicornis (One-horned Rhino), Ursus thibetanus, Capra sp., and Felis sp. (Wild cat).
Apatani, Nyishi, Monpa of Arunachal Pradesh; Karbi and

Biate of Assam; Ethnic groups of Manipur; Mizo of

Mizoram; Ao, Angami, Sema, Sangtam, Khiamniungan,

Yimchunger, Chakhesang, Lotha, Zeliang, Pochury and

Rengma of Nagaland; Lepcha, Bhutia and Nepali of

Sikkim.

Apatani, Nyishi, Monpa, Tangsa and Wancho of Arunachal Pradesh; Ahom, Chutia, Koch-Rajbonshi, Kalita and Adivasis, Nath and Karbi of Assam; Ethnic groups of Manipur; Mizo, Bru and Chakma of Mizoram; Ao, Angami, Sema, Sangtam, Khiamniungan,

Yimchunger, Chakhesang, Lotha, Zeliang, Pochury and Rengma of Nagaland; Lepcha, Bhutia and Nepali of Sikkim; Tripuri, Jamatia and Reang of Tripura.

Nyishi, Tangsa of AP; Nath and Karbi of Assam; Ethnic groups of Manipur; Mizo of Mizoram; Ao, Angami, Sema, Sangtam, Khiamniungan, Yimchunger,

Chakhesang, Lotha, Zeliang, Pochury and Rengma of Nagaland; Lepcha, Bhutia and Nepali of Sikkim.
Lalramnghinglova (1999); Jamir and Lal

(2005); Kakati et al. (2006); Solanki and Chuti (2009); Hanse and Teron (2012); Teronpi et al. (2012); Betlu (2013); Verma et al. (2014); Devi et al. (2015); Dhakal et al. (2019).

Lalramnghinglova (1999); Jamir and Lal (2005); Kakati et al. (2006); Solanki and Chutia (2009); Verma et al. (2014); Das (2015); Devi et al. (2015); Borah and Prasad (2017); Dhakal et al. (2019); Jugli et al. (2019).

Solanki et al. (2004); Jamir and Lal (2005);

Kakati et al. (2006); Hanse and Teron (2012); Teronpi et al. (2012); Devi et al. (2015); Borah and Prasad (2016); Dhakal et al. (2019); Jugli et al. (2019). 


\begin{tabular}{ll}
\hline Joint pain & Bagarius sp., Python molurus, Ursus thibetanus (Asiatic Black \\
(13 species) & Bear), Pteropus medius (Flying fox), Canis aureus, \\
& Capricornis sumatraensis (Mainland serow), Sus scrofa
\end{tabular}
Capricornis sumatraensis (Mainland serow), Sus scrofa domesticus (Pig), Xenentodon cancila (Freshwater gar fish), Echis coloratus (Viper), Struthio camelus (Common Ostrich), Macaca mullata (Rhesus macaque), Buceros bicornis (Hornbill), and Apis dorsata (Giant bee).

Fever (21 species) Apis sp., Oecophylla smaragdina, Selenarctos thibetanus, Bunopithecus hoollock, Cynopterus sphinx (Bat), Maydelliathelphusa lugubris (Fresh water crab), Canis familiaris (Dog), Vulpes sp., Leptocorisa varicornis (Rice bug insect), Hystrix indica, Cyprinus carpio (Common carp), Bos indicus (Cow), Manis pentadactyla (Chinese pangolin), Bandicota sp. (Mole), Herpestes sp. (Mongoose), Corvus macrorhynchos (Large billed crow), Aorichthys seenghala (Fish), Mastacembelus armatus, Cervus sp. (Deer), Trachypithecus pileatus, and Macaca assamensis.

Weakness (27 species)

Cervus unicolor (Sambar), Macaca assamensis, Monopterus cuchia, Axis porcinus (Hog deer), Bos grunniens (Yak),

Moschus moschiferus (Musk deer), Capricornis sumtraensis, Naemorhedus goral, Pseudois nayaur, Budorcas taxicolor, Bo frontalis, Vulpes bengalensis (Fox), Hoolock leuconedys, Columba livia, Monopterus sp., M. armatus (Spiny eel fish), Clarias batrachus (Walking catfish), Python molurus, Palaemon sp. (Prawn), Prionailurus bengalensis (Leopard cat), Columba sp., Capra sp., Wallago attu (Cat Fish), Selenarctos sp., Varanus bengalensis, Civettiictis civett (Civet), and Haliaeetus sp. (Eagle).

Female problems (23 species) Chiroptera sp. (Bat), Hystrix indica, Python molursus, Macaca assamensis, Rhyticeros undulatus ticehursti (Wheathead hornbill), Hylobates hoolock, Bos frontalis (Mithun), Capra hircus, Rattus sp. (Rat), Vulpes bengalensis (Fox), M. armatus (Spiny eel fish), Ursus thibetanus, Canis lupus familiaris (Dog), Platanista gangetica (River dolphin), Monopterus cuchia (Cuchia fish), Clarias batrachus (Magur fish), Heteropneustes fossilis (Fish), Labeo pangusia (Fish), Lepus capensis (Rabbit), Luthra perspicillata perspicillata (Otter), Colisa sota (Fish), Manis crassicaudata, and Cervus/Machus sp. (Deer).
Nyishi, Galo, and Tangsa of Arunachal Pradesh; Karbi, Biate, Nath of Assam; Mizo of Mizoram; Tripuri, Jamatia and Reang of Tripura; Lepcha, Bhutia and Nepali of Sikkim; Rongmei Manipur.

Nyishi, Galo, Monpa and Tangsa of AP; Karbi, Ahom, Chutia, Koch-Rajbonshi, Kalita and Adivasis of Assam; Mizo of Mizoram; Tripuri, Jamatia and Reang of Tripura; Lepcha, Bhutia and Nepali of Sikkim; Meitei, Meitei Pangals, Chothe, Kabui, Kom of Manipur; Ao, Angami, Sema, Sangtam, Khiamniungan, Yimchunger,

Chakhesang, Lotha, Zeliang, Pochury and Rengma of Nagaland.

Apatani, Nyishi, Monpa, Tangsa, Wancho of AP; Mizo of Mizoram; Tripuri, Jamatia and Reang of Tripura; Ethnic groups of Manipur; Ao, Angami, Sema, Sangtam,

Khiamniungan, Yimchunger, Chakhesang, Lotha, Zeliang, Pochury and Rengma of Nagaland.

Adi, Apatani, Nyishi, Monpa, Galo, Tangsa, Wancho of AP; Biate, Nath, Karbi and Dimasa of Assam; Meitei, Meitei Pangals, Chothe (Lamlanghupi), Kabui (Nambol) Kom communities; Rongmei of Manipur; Mizo, Bru, Chakma of Mizoram; Ao, Angami, Sema, Sangtam,

Khiamniungan, Yimchunger, Chakhesang, Lotha, Zeliang, Pochury and Rengma of Nagaland.
Hanse and Teron (2012); Betlu (2013); Verma et al. (2014); Das (2015); Borah and Prasad (2016); Ngaomei and Singh (2016); Dhakal et al. (2019); Jugli et al. (2019).

Solanki et al. (2004); Jamir and Lal (2005); Hanse and Teron (2012); Das (2015); Chanu et al. (2016); Borah and Prasad (2017); Dhakal et al. (2019); Jugli et al. (2019).

Lalramnghinglova (1999); Jamir and Lal (2005); Kakati et al. (2006); Solanki and Chutia (2009); Chinlampianga et al. (2013); Das (2015); Devi et al. (2015); Jugli et al. (2019).

Lalramnghinglova (1999); Kakati and Doulo (2002); Jamir and Lal (2005); Solanki et al. (2005, 2016); Teronpi et al. (2012); Chinlampianga et al. (2013); Betlu (2013); Verma et al. (2014); Devi et al. (2015); Borah and Prasad (2016); Chanu et al. (2016); Ngaomei and Singh (2016); Jugli et al. (2019). 


\begin{tabular}{ll}
\hline Fractures & M. ursinus (Sloth Bear), Pila sp., Gallus domesticus (Chicken), \\
(11 species) & Hylobates hoolock, Xestina sp., Sus scrofa domestica, \\
& Hemitragus jemlahicus, Naja sp. (Cobra), Hystrix sp., Capra \\
& sibirica, and Aquila rapax (Eagle).
\end{tabular}

Animal/insect Apis sp., Python molurus, Hystrix brachyuran, Canis lupus bites

(14 species) familiaris (Dog), Viverra zibetha (Large Indian civet), Vespa orientalis (Oriental hornet), Maydelliathelphusa lugubris

(Freshwater crab), Eutropis carinata (Common Indian skink), Capra hircus, Bufo melanostictus (Toad), Hylobates hoolock, Pheretima sp. (Earthworm), Varanus bengalensis, and Sus sp. (Pig).

Anemia

(6 species)

Monopterus cuchia (Eel Fish), Bos indicus, Hylobates hoolock Clarias batrachus, Heteropneustes fossilis (Catfish), and Maschus sp. (Musk Deer).

Male

impotency

(15 species)

Muntiacus muntjak (Barking deer), Bos grunniens (Yak), Budorcas taxicolor, Bos frontalis, Capricornis sumatraensis (Serow), Naemorhedus goral (Goral), Pseudois nayaur, Gekko gecko (Tokay gecko), Passer domesticus (House sparrow), Cryptozona bistrialis (Snail), Gallus gallus, Myotis lucifugus (Bat), Canis familiaris, Herpestes sp., and Aquila sp.

Diabetes (17 species)

Penaeus indicus (Prawn), Puntius sp., Scylla serrata (Crab), Bufo melanostictus (Toad), Tehanochelys trijuga (Turtle), Monopterus cuchia, Ophiophagus hannah (King cobra), Eonycteris spelaea (Bat); Ursus thibetanus, Capricornis sumatraensis, Macaca assamensis, Manis sp., Petaurista petaurista (Red giant flying squirrel), Hystrix sp., Uttaney musa (Mole), Bos taurus (cattle), and Periplaneta americana.
Nyishi of AP; Ahom, Chutia, Koch-Rajbonshi, Kalita, Adivasis, Nath and Karbi of Assam; Mizo of Mizoram; Ao, Angami, Sema, Sangtam, Pochury, Lotha,

Khiamniungan, Yimchunger, Chakhesang, Zeliang, and Rengma of Nagaland; Tripuri, Lepcha, Bhutia and Nepali of Sikkim; Jamatia and Reang of Tripura.

Apatani, Nyishi, Monpa, Tangsa of Arunachal Pradesh; Biate, Ahom, Chutia, Koch-Rajbonshi, Kalita and Adivasis of Assam; Ethnic groups of Manipur; Mizo Mizoram; Ao, Angami, Sema, Sangtam, Lotha,

Khiamniungan, Yimchunger, Zeliang, Chakhesang,

Pochury and Rengma of Nagaland; Lepcha, Bhutia and Nepali of Sikkim.

Karbi of Assam; Meitei, Pangals, Chothe, Kabui, Kom of Manipur; Mizo of Mizoram; Ao, Angami, Sema, Sangtam, Khiamniungan, Yimchunger, Chakhesang, Lotha, Zeliang, Pochury and Rengma of Nagaland.

Apatani, Nyishi and Monpa of AP; Biate, Ahom, Chutia, Koch-Rajbonshi, Kalita and Adivasis of Assam; Rongmei of Manipur; Ao, Angami, Sema, Sangtam, Khiamniungan, Yimchunger, Chakhesang, Lotha, Zeliang, and Rengma of Nagaland; Tripuri, Jamatia and Reang of Tripura.

Adi of Arunachal Pradesh; Rural communities of Dibrugarh, and Biate of Assam; Mizo, Bru and Chakma of Mizoram; Ethnic groups of Manipur; Lepcha, Bhutia and Nepali of Sikkim.
Lalramnghinglova (1999); Kakati and Doulo (2002); Solanki et al. (2004); Jamir and Lal (2005); Kakati et al. (2006); Das (2015); Borah and Prasad (2017); Dhakal et al. (2019).

Lalramnghinglova (1999); Jamir and Lal (2005); Kakati et al. (2006); Solanki and Chutia (2009); Betlu (2013); Devi et al. (2015); Borah and Prasad (2017); Dhakal et al. (2019); Jugli et al. (2019).

Lalramnghinglova (1999); Kakati and Doulo (2002); Jamir and Lal (2005); Teronpi et al. (2012); Verma et al. (2014); Devi et al. (2015); Chanu et al. (2016).

Jamir and Lal (2005); Kakati et al. (2006); Solanki and Chutia (2009); Betlu (2013); Das (2015); Ngaomei and Singh (2016); Borah and Prasad (2017).

Kalita et al. (2005); Chinlampianga et al. (2013); Betlu (2013); Devi et al. (2015); Solanki et al. (2016); Dhakal et al. (2019). 
Table 4. Conservation status (IUCN 2020) of animals used for ethno-zoological applications in NE India

\begin{tabular}{|c|c|}
\hline Name of the animal species & $\begin{array}{c}\text { IUCN } 2020 \\
\text { status }\end{array}$ \\
\hline Amblypharyngodon mola (Indian Carpet Fish) & LC \\
\hline Amphipnous cuchia (Cuchia) & $\mathrm{LC}$ \\
\hline Antilocapra americana (Antelope) & $\mathrm{LC}$ \\
\hline Bufo melanostictus (Toad) & $\mathrm{LC}$ \\
\hline Canis aureus (Golden Jackal) & $\mathrm{LC}$ \\
\hline Centropus sinensis (Greater Coucal) & $\mathrm{LC}$ \\
\hline Chaca chaca (Fish) & $\mathrm{LC}$ \\
\hline Channa punctatus (Snakehead fish) & $\mathrm{LC}$ \\
\hline Civettictis sp. (Civet) & $\mathrm{LC}$ \\
\hline Clarias batrachus (Magur fish) & $\mathrm{LC}$ \\
\hline Columba livia (Pigeon) & $\mathrm{LC}$ \\
\hline Crotalus durissus (Neotropical Rattle Snake) & $\mathrm{LC}$ \\
\hline Cynopterus sphinx (Bat) & $\mathrm{LC}$ \\
\hline Echis coloratus (Viper) & $\mathrm{LC}$ \\
\hline Eutropiichthys vacha (Fish) & $\mathrm{LC}$ \\
\hline Eutropis carinata (Common Indian skink) & $\mathrm{LC}$ \\
\hline Felis silvestris (Wild Cat) & $\mathrm{LC}$ \\
\hline Gallus domesticus (Chicken) & $\mathrm{LC}$ \\
\hline Gekko gecko (Tokay Gecko) & $\mathrm{LC}$ \\
\hline Herpestes sp. (Mongoose) & $\mathrm{LC}$ \\
\hline Heteropneustes fossilis (Singing catfish) & $\mathrm{LC}$ \\
\hline Hystrix indica (Indian Porcupine) & $\mathrm{LC}$ \\
\hline Labeo rohita (Fish) & $\mathrm{LC}$ \\
\hline Lepus capensis (Rabbit) & $\mathrm{LC}$ \\
\hline Lepus nigricollis (Hare) & $\mathrm{LC}$ \\
\hline Lymnaea sp. (Water snail) & $\mathrm{LC}$ \\
\hline Macaca mulatta (Rhesus Macaque) & $\mathrm{LC}$ \\
\hline Mantis religiosa (Praying Mantis) & $\mathrm{LC}$ \\
\hline Martes flavigula (Yellow Throated Marten) & $\mathrm{LC}$ \\
\hline Mastacembelus armatus (Spiny Eel Fish) & $\mathrm{LC}$ \\
\hline Maydelliathelphusa lugubris (Fresh Water Crab) & $\mathrm{LC}$ \\
\hline Megalaima sp. (Barbet) & $\mathrm{LC}$ \\
\hline Mus musculus (House mouse) & $\mathrm{LC}$ \\
\hline Mustela sp. (Weasel) & $\mathrm{LC}$ \\
\hline Mystus bleekeri (Fish) & $\mathrm{LC}$ \\
\hline Naja naja (Cobra) & $\mathrm{LC}$ \\
\hline Nanorana liebigii (Frog) & $\mathrm{LC}$ \\
\hline Petaurista petaurista (Red Giant Flying Squirrel) & $\mathrm{LC}$ \\
\hline Pheretima sp. (Earthworm) & $\mathrm{LC}$ \\
\hline Picus canus (Black Napped Green Woodpecker) & $\mathrm{LC}$ \\
\hline Polypedates leucomystax (Common Tree Frog) & $\mathrm{LC}$ \\
\hline Prionailurus bengalensis (Leopard Cat) & $\mathrm{LC}$ \\
\hline Pseudois nayaur (Himalayan Blue Sheep) & $\mathrm{LC}$ \\
\hline Pteromys sp. (Flying Squirrel) & $\mathrm{LC}$ \\
\hline Puntius sp. (Fish) & $\mathrm{LC}$ \\
\hline Rana sp. (Frog) & $\mathrm{LC}$ \\
\hline Rattus sp. (Rat) & $\mathrm{LC}$ \\
\hline Rhizomys sumatrensis (Bamboo Rat) & $\mathrm{LC}$ \\
\hline Sartoriana sp. (Red Freshwater Crab) & $\mathrm{LC}$ \\
\hline Scylla sp. (Mud crabs) & $\mathrm{LC}$ \\
\hline Struthio camelus (Common Ostrich) & $\mathrm{LC}$ \\
\hline Sus scrofa domestica $(\mathrm{Pig})$ & $\mathrm{LC}$ \\
\hline Talpa sp. (Hill mole) & $\mathrm{LC}$ \\
\hline Varanus bengalensis (Monitor Lizard) & $\mathrm{LC}$ \\
\hline Viverra zibetha (Large Indian Civet) & $\mathrm{LC}$ \\
\hline Viverricula indica (Small Indian Civet) & $\mathrm{LC}$ \\
\hline Vulpes bengalensis (Fox) & $\mathrm{LC}$ \\
\hline Xenentodon cancila (Freshwater Gar Fish) & $\mathrm{LC}$ \\
\hline Arctonyx collaris (Hog badger) & VU \\
\hline Buceros bicornis (Great Hornbill) & VU \\
\hline Buceros sp. (Hornbill) & VU \\
\hline Budorcas taxicolor (Takin) & VU \\
\hline
\end{tabular}

\begin{tabular}{|c|c|}
\hline Cyprinus carpio (Common Carp) & $\mathrm{VU}$ \\
\hline Dicrurus sp. (Drongo) & VU \\
\hline Haliaeetus sp. (Eagle) & VU \\
\hline Helarctos malayanus (Malayan sun bear) & VU \\
\hline Hoolock leuconedys (Eastern Hoolock Gibbon) & VU \\
\hline Lutrogale perspicillata (Smooth Coated Otter) & VU \\
\hline Melursus ursinus (Sloth bear) & VU \\
\hline Neofelis nebulosa (Clouded Leopard) & VU \\
\hline Ophiophagus hannah (King Cobra) & VU \\
\hline Panthera pardus (Leopard) & VU \\
\hline Pteropus sp. (Flying Fox) & VU \\
\hline Python molurus (Indian Python) & VU \\
\hline Rhinoceros unicornis (Rhino) & VU \\
\hline Semiplotus sp. (Fish) & VU \\
\hline Trachypithecus pileatus (Capped Langur) & VU \\
\hline Ursus thibetanus (Himalayan Black Bear) & VU \\
\hline Wallago attu (Fish) & VU \\
\hline Amblyceps sp. (Catfish) & EN \\
\hline Anguilla sp. (Eel) & EN \\
\hline Axis porcinus (Hog Deer) & EN \\
\hline Bubalus arnee (Wild Water Buffalo) & EN \\
\hline Manis crassicaudata (Indian Pangolin) & EN \\
\hline Moschus sp. (Musk Deer) & EN \\
\hline Nycticebus sp. (Slow loris) & EN \\
\hline Panthera tigris (Tiger) & EN \\
\hline Platanista gangetica (River Dolphin) & EN \\
\hline Bagarius sp. (Gangetic Goonch) & NT \\
\hline Hemitragus jemlahicus (Himalayan Tahr) & NT \\
\hline Labeo pangusia (Fish) & NT \\
\hline Macaca assamensis (Assamese Macaque) & NT \\
\hline Naemorhedus goral (Himalayan Goral) & NT \\
\hline Pardofelis sp. (Marbled cat) & NT \\
\hline Testudo sp. (Tortoise) & NT \\
\hline Chiroptera sp. (Bat) & $\mathrm{CR}$ \\
\hline Geochelone emys (Eastern Hill Tortoise) & $\mathrm{CR}$ \\
\hline Manis sp. (Pangolin) & $\mathrm{CR}$ \\
\hline Callosciurus (Oriental Tree Squirrel) & DD \\
\hline
\end{tabular}

Note: LC: Least Concern; VU: Vulnerable; EN: Endangered; NT: Near Threatened; CR: Critically Endangered; DD: Data Deficient

\section{Discussion}

This study is an attempt to highlight the available knowledge on ethno-zoological therapeutic applications used by different traditional healers and indigenous communities of northeast India. Ethno-medicinal practices have been well known and in use for a long time, but reportedly limited pertaining to studies based on animals in NE India. Such studies on animal-based medicines and their mode of application in NE India are relatively limited and fragmentary due to various reasons that also include the oral transmission of knowledge that gradually declines among local communities. Analysis of literature helped us to discover the traditional cure of ailments with ethnozoological treatments practiced by various tribes of NE India (Solanki and Chutia 2004; Jamir and Lal 2005; Kakati et al. 2006; Verma et al. 2014).

The present investigation shows that various indigenous communities use animals in their traditional medicines in all of the eight NE Indian states (Table 2-3). In Arunachal Pradesh, the use of animal-based medicines by traditional 
healers was never reported systematically earlier, except for a few reports from Pandey et al. (1999), Solanki (2002), Solanki et al. (2004), Solanki and Chutia (2004), Solanki (2006) and Chutia (2006) in the $21^{\text {st }}$ century. A review of literature in Arunachal Pradesh reveals that large-scale use of animal-based ethnomedicine still remained largely undocumented in the state. In Assam, reviews of the available information on ethno-zoological therapeutic procedures and the use of particular organs/body parts of animals for specific diseases are still unexplored and fragmentary; which is believed to be large because local healers share their formulations of therapeutic products with a highly conservative approach. Whole body, meat, soft watery section, etc. are some of the ways the local and traditional healers use animal parts/organ in applying traditional disease healing in Assam. In Manipur, animal parts such as skin, hair, bones, animals and by-products such as urine are usually used in zoo-therapeutic treatments; and secretions of the gland are used in magicoreligious and faith-healing rituals; while endoskeletons and exoskeletal parts of animals are used as "charms" to expel evil spirits (Devi et al. 2015).

In Meghalaya, Mizoram, Nagaland, Sikkim and Tripura the application of use of mammals and mammalian products have been observed to be highest, including Arunachal Pradesh and Assam. In Sikkim, Dhakal et al. (2019) stated that parts of the body used in their ethnozoological medicinal applications included bones, meat, teeth, gall bladder, skin, musks and horns used for dysentery, fractures, tuberculosis, common cough and cold and fever, diabetes, malaria, and piles. In Tripura, Das (2015) had reported that several parts of the body, such as urine, blood, flesh, entire body, feces, etc. are usually used for diagnosis of human ailments depending on the type of ailment and its possible mode of action.

Application of fish-based medicines in the state of Manipur is prevalent compared to other animal species (Figure 4). In Arunachal Pradesh, use of insects is the highest in traditional medicine in comparison to other states (Figure 2). Several other animal groups such as birds, rodents, amphibians, annelids, mollusks, crustaceans, and arachnids are also used for traditional medicines in these communities depending on the type of ailments.

\section{Application of mammals}

All NE Indian states, excluding Manipur, recorded the highest use of mammals as compared to other species of animals. Similar findings have also been reported in other parts of India, where use of mammals in traditional medicine is comparatively higher than use of other animal groups (Mahawar and Jaroli 2008). Jaroli et al. (2010) and Chellappandian et al. (2014) were of the opinion that mammals are readily accessible for optimal use in traditional medicine. However, Dhakal et al. (2019) were of the opinion that increased use of mammals may be attributed to the growing number of domesticated mammals and the ethnic communities' association with mammals.

\section{Application of fishes}

The review shows that for indigenous communities of NE India, fish have also been the essential resource for traditional medicines, apart from being a good nutrient intake and an integral part of folk ritual. This is evident from the studies conducted in Manipur, resulting in their overuse and thereby leading to over-exploitation (Devi et al. 2015; Chanu et al. 2016). Chanu et al. (2016) stated that the use of Channa orientalis in different types of traditional medicines and religious purposes is one of the reasons for drastic reduction of this fish species in the natural habitats. Another example is the use of Channa orientalis and Channa punctatus as 'goodwill charms' amongst some tribes in Manipur during marriage ceremonies, New Year's Day of Meitei tribes, taken in fermented forms by ailing patients. The skin, eyes, whole body, flesh and scales are widely used body parts of fish for therapeutics. (Devi et al. 2015).

\section{Application of insects}

In addition to mammals and fish, insects were also observed as one of the most important sources of ethnomedicine in NE India. Traditional knowledge and acceptance of insects as food and for local therapies have been found to be highly prevalent in Arunachal Pradesh (Dagyom and Gopi 2009; Chakravorty et al. 2011a), Meghalaya (Mihsill and Keshan 2011) and with lesser use in other states of NE India. It is observed that insects are used during the larva stages, pupal stages and also in adult stages in traditional medicine (Chakravorty et al. 2011a). Rodriguez and Levin (1976) believed that since insects and plants use similar chemical compounds for defense mechanisms, the use of pharmacological activities from such insect species that feed on plants producing drugs becomes a potential source of ethno-zoological medicines.

\section{Application of animal body parts}

Flesh, meat, bones, bone marrow, fats, gall bladder, food pipe, reproductive organs, horns, feather and legs of birds, animal fetuses, fat, hair, skin, liver, teeth, musks, ears, tongue, neck, hands, arms, skin and male organs are widely used in NE India (Table 2). It is also observed that in ethnomedicine animal products like urine, blood, bile juice, milk, and soft watery portions were used.

The review shows that there is still lack of research on traditional medicines based on animals by the indigenous communities of NE India, especially in the state of Meghalaya, Mizoram, Nagaland, Sikkim and Tripura (Table 2-3). Further, documentation needs to be carried out with respect to traditional medicines based on animals by Garo, Jaintia and Bhoi communities of Meghalaya. Use of elephant teeth in food poisoning by the Khasi community of Meghalaya needs to be documented.

\section{CONCLUDING REMARKS}

Traditional medicine using animals has been playing vital roles in the ethnic health care system for ages. However, equally vital is the fact that taking utmost care of 
ecological balance while practicing traditional medicines using animals and animal products requires attention to conserve our rich biodiversity. Gradual changes in ecosystem patterns as a result of deforestation, jhum farming, uncontrolled fishing, etc., lack of awareness of conservation and preservation, and other factors, have posed serious threat to the existing ethnomedicinal plants and animals in NE India (Yirga et al. 2011). The traditional ethnomedicinal practices require prompt recognition by authorities and further strengthening with the help of incentivized training and education programs (Dhakal et al. 2019). Creation of database on the practitioners and the mode of treatment would prioritize creation of policies and regulations thereby enforcing a safeguard on natural resource exploitation. Responsible roles by the traditional healers while practicing local medicine would lead to an effective balance between nature and traditional medicine. An integrated approach towards potential uses of traditional medicine using animals would not only conserve our rich natural resources, but also aid in preserving cultural heritage as well. For aquatic species, a conservation and sustainable strategy need to be implemented while utilizing these species for traditional health practices. Additionally, scientific awareness, management and conservation measures of animal resources would enhance better connectivity with nature.

NE India accounts for only $8 \%$ of the geographical area of India; however, around $60 \%$ of the country's endangered species flourish in the region (Choudhury 2006). There are many species that are native to this area, such as the Indian Rhinoceros, Wild Buffalo, primate species, etc., used for ethno-zoological applications. Several primates are reportedly believed to have been hunted in Arunachal Pradesh, Assam, Mizoram, and Tripura, and for several superstitious beliefs and possession of medicinal properties (Gupta et al. 2014). Aiyadurai (2011) recorded that out of a total of 50 native Indian species of Galliformes (land fowls), 32 occur exclusively in NE India. The share of NE India is relatively high in the case of 'Vulnerable' birds and reptiles: $74 \%$ and $80 \%$ respectively (Choudhury 2006). Gupta et al. (2014) recorded that 11 of the 16 primate species in India are recorded to live in NE India; and with the exception of three species, due to many anthropogenic activities, remaining primate species have faced serious threats. As recorded by Gupta et al. (2014), other species known to be endangered in North-eastern states due to several anthropogenic pressures include slow loris, tiger, leopard, bear, serow, goral, yak, sheep, pangolin, river dolphin and several bird and reptile species. Present study also reflects that several vulnerable, endangered, near threatened and critically endangered species are being used for ethno-zoological applications in NE India (Table 4).

Wildlife hunting poses a high risk to the survival of wildlife species in this area due to the fact that indigenous communities of the North-East are largely dependent on ethnozoological applications for traditional medicine (Aiyadurai 2011; Gupta et al. 2014). A major reason why wildlife hunting is seen as a difficult problem to address is the relation between hunting and the socio-economic needs of local people; and the same balance needs to reduce the adverse effect of hunting on wildlife populations and the reliance of rural communities on wildlife for food, medicine, etc. (Aiyadurai 2011). Long-term conservation measures such as education, eco-tourism, and the establishment of more protected areas may be necessary to provide a sustainable existence of ethnomedicinal applications as well as the conservation of endangered species in order to cover as much habitat as possible and to check for habitat destruction, fragmentation, deforestation, wildlife hunting and pollution, which are critical to the existence of diverse species in the region. In addition, a database of available species will provide a deeper understanding of the conservation strategy and of the region's species composition.

The traditional healers need to be sensitized and made aware of the extant Acts and Rules pertaining to wildlife conservation (Tynsong et al. 2020). However, ethnozoological application of animals is a matter of serious concern connected with illegal trade in wildlife where animal parts/animal products such as gall-bladder of Himalayan Black Bear, goral horns, pangolin scales, monkey flesh, etc. are rarely available (Dhakal et al. 2019). Reports indicate that subsequently, scarcity has led to a decline in ethno-zoological traditional medicines among indigenous communities in Sikkim (Dhakal et al. 2019). Studies conducted by Dhakal et al. (2019) also suggest amphibian species such as Nanorana liebegii and Amolops himalayanus have a high value of ethnomedicinal properties in zoo therapy and are therefore prone to overexploitation.

\section{ACKNOWLEDGEMENTS}

The authors declare that there's no conflict of interest concerning the publication of this paper. The opinion expressed within the paper is of the authors and not of the organization to they belong. The authors are grateful to the Deputy Director-General of Forests (C), IRO Shillong for her constant support and encouragement.

\section{REFERENCES}

Adeola MO. 1992. Importance of Wild Animals and their parts in the culture, religious festivals, and traditional medicine, of Nigeria. $\begin{array}{llll}\text { Environ } & \text { Conserv } 19 & \text { (2): } 125-134 . & \end{array}$ 10.1017/S0376892900030605.

Aiyadurai A. 2011. Review: Wildlife hunting and conservation in Northeast India: A need for an interdisciplinary understanding. Int $\mathbf{J}$ Gall Conserv 2: 61-73.

Alves RRN, Rosa IL. 2005. Why study the use of animal products in traditional medicine? J Ethnobiol Ethnomed 1 (1): 5. DOI: 10.1186/1746-4269-1-1.

Alves RRN. 2012. Relationships between fauna and people and the role of ethnozoology in animal conservation. Ethnobiol Conserv 1: 1-69. DOI: 10.15451/ec2012-8-1.2-1-69.

Anageletti LR, Agrimi U, Curia C, French D, Mariani-Costantini R. 1992. Healing rituals and sacred serpents. Lancet 340: 223-225. DOI: 10.1016/0140-6736(92)90480-Q.

Betlu ALS. 2013. Indigenous knowledge of zootherapeutic use among the Biate tribe of Dima Hasao District, Assam, North-eastern India. J Ethnobiol Ethnomed 9: 1-15. DOI: 10.1186/1746-4269-9-56. 
Bhatti RC, Nirmala C, Kaur A, Singh S, Kumar P, Kaur R, Singh AN. 2017. Harnessing of local plant species by indigenous people of Hamirpur district for ethno-veterinary purposes. Ann Plant Sci 6 (12): 1898-1925. DOI: 10.21746/aps.2017.6.12.17.

Borah MP, Prasad SB. 2017. Ethnozoological study of animals-based medicine used by traditional healers and indigenous inhabitants in the adjoining areas of Gibbon Wildlife Sanctuary, Assam, India. J Ethnobiol Ethnomed 13 (1): 39. DOI: 10.1186/s13002-017-0167-6.

Borah MP, Prasad SB. 2016. Ethnozoological remedial uses by the indigenous inhabitants in Adjoining Areas of Pobitora Wildlife Sanctuary, Assam, India. Intl J Pharm Pharm Sci 8 (4): 90-96.

Cavendish W. 2000. Empirical regularities in the poverty-environment relationship of rural households: Evidence from Zimbabwe. World Dev 28: 1979-2003. DOI: 10.1016/S0305-750X(00)00066-8.

Chakraborty R, De B, Devanna N, Sen S. 2012. North-East India an ethnic storehouse of unexplored medicinal plants. J Nat Prod Plant Resour 2 (1): 143-152.

Chakravorty J, Ghosh S, Meyer-Rochow VB. 2011a. Practices of entomophagy and entomotherapy by members of the Nyshi and Galo tribes, two ethnic groups of the state of Arunachal Pradesh (NorthEast India). J Ethnobiol Ethnomed 7 (1): 5. DOI: 10.1186/1746-42697-5.

Chakravorty J, Meyer-Rochow VB, Ghosh S. 2011b. Vertebrate used for medicinal purposes by members of the Nyishi and Galo tribes in Arunachal Pradesh (North-East India). J Ethnobiol Ethnomed 7 (1): 1 14. DOI: $10.1186 / 1746-4269-7-13$

Chanu TA, Teron R, Singh SK. 2016. Ethnomedicinal use of certain fish species by ethnic groups of Bishnupur District in Manipur, NE India. World J Environ Biosci 5 (2): 1-5.

Chellappandian M, Pandikumar P, Mutheeswaran S, Paulraj MG Prabakaran S, Duraipandiyan V, Ignacimuthu S, Al-Dhabi NA. 2014 Documentation and quantitative analysis of local ethnozoological knowledge among traditional healers of Theni district, Tamil Nadu, India. J Ethnopharmacol 154 (1): 116-130. DOI 10.1016/j.jep.2014.03.028.

Chinlampianga M, Singh RK, Shukla AC. 2013. Ethnozoologica diversity of Northeast India: Empirical learning with traditiona knowledge holders of Mizoram and Arunachal Pradesh. Indian J Tradit Knowl 12 (1): 18-30.

Choudhury A. 2006. The status of endangered species in Northeast India. J Bombay Nat Hist Soc 103 (2-3): 157-167.

Chutia P. 2006. Ethnozoological study of Nyishi, Monapa, and Apatani tribes of Arunachal Pradesh. [Dissertation]. North-Eastern Hill University, Shillong, Meghalaya. [Indian]

Costa-Neto EM. 2005. Animal-based medicines: Biological prospection and the sustainable use of zootherapeutic resources. An Acad Bras Ciênc 77 (1): 33-43. DOI: 10.1590/S0001-37652005000100004

Costa-Neto EM. 1999. Healing with animals in Feira de Santana city, Bahia, Brazil. J Ethnopharmacol 65: 225-230. DOI: 10.1016/S03788741(98)00158-5.

Dagyom K, Gopi GV. 2009. Ethnozoology of Galo tribe with special reference to edible insects in Arunachal Pradesh. Indian J Tradit Knowl 8 (1): 81-83.

Das AK, Dutta BK, Sharma GD. 2008. Medicinal plants used by different tribes of Cachar district, Assam. Indian J Tradit Knowl 7 (3): 446454.

Das D. 2015. Ethnozoological practices among tribal inhabitants in Khowai District of Tripura, North-East India. J Glob Biosci 4 (9): 3364-3372.

Das HB, Majumdar K, Datta BK, Ray D. 2009. Ethnobotanical uses of some plants by Tripuri and Reang tribes of Tripura. Nat Prod Radiance 8 (2): 172-180.

Debbarma M, Pala MA, Kumar M, Bussmann RW. 2017. Traditional knowledge of medicinal plants in tribes of Tripura in Northeast, India. Afr J Tradit Complement Altern Med 14 (4): 156-168. DOI 10.21010/ajtcam.v14i4.19.

Devi OB, Devi LR, Singh WM, Devi AK. 2015. Traditional medicines and health care from the animals of Manipur, India. Intl J Sci Res Publ 5 (11): 417-422

Dhakal P, Chettri B, Lepcha S, Acharya BK. 2019. Rich yet undocumented ethnozoological practices of socio-culturally diverse indigenous communities of Sikkim Himalaya, India. J Ethnopharmacol 249: 112386. DOI: 10.1016/j.jep.2019.112386

Dutta BK, Dutta PK. 2005. Potential of ethnobotanical studies in Northeast India: An overview. Indian J Tradit Know 4 (1): 7-14.
Faruque MO, Uddin SB, Barlow JW, Hu S, Dong S, Cai Q, Li X, Hu X. 2018. Quantitative ethnobotany of medicinal plants used by indigenous communities in the Bandarban District of Bangladesh. Front Pharmacol 9 (40): 1-12. DOI: 10.3389/fphar.2018.00040.

Gupta AK, Daschaudhuri D, Bhattacharjee B, Datta M. 2014. North-East Biodiversity and Sustainable Economic Development Issues and Challenges. Concept Publishing Company Pvt. Ltd.

Hanse R, Teron R. 2012. Ethnozoological practices among The Karbi Tribe in Karbi Anglong District of Assam (India). In: The EcoScan, Special Issue, Proceedings of International Conference on Anthropogenic Impact on Environment and Conservation Strategy. ISSN: $0974-0376,1: 117-120$.

Harit DN. 2001. Zoo therapeutic use of animals in healthcare in Mizoram, India. J Nat Conserv 13 (1): 117-122.

Hynniewta SR, Yogendra K. 2008. Herbal remedies among the Khasi traditional healers and village folks in Meghalaya. J Trad Knowl 7 (4): 581-586.

International Union for Conservation of Nature (IUCN). 2020. Version 2020-2. https://www.iucnredlist.org

Jamir NS, Lal P. 2005. Ethnozoological practice among Naga tribes. Indian J Tradit Knowl 4 (1): 100-104.

Janes CR. 1999. The health transition, global modernity and the crisis of traditional medicine: The Tibetan case. Soc Sci Med 48: 1803-1820. DOI: 10.1016/S0277-9536(99)00082-9.

Jaroli DP, Mahawar MM, Vyas N. 2010. An ethnozoological study in the adjoining areas of Mount Abu wildlife sanctuary, India. J Ethnobiol Ethnomed 6 (6): 1-8. DOI: 10.1186/1746-4269-6-6.

Jugli S, Chakravorty J, Meyer-Rochow VB. 2019. Zootherapeutic uses of animals and their parts: an important element of the traditional knowledge of the Tangsa and Wancho of eastern Arunachal Pradesh, North-East India. Environ Dev Sustain. DOI: 10.1007/s10668-019. 00404-6.

Kakati LN Doulo V. 2002. Indigenous knowledge system of zootherapeutic use by Chakhesang tribe of Nagaland, India. J Hum Ecol 13 (6): 419-423. DOI: 10.1080/09709274.2002.11905579.

Kakati LN, Ao B, Doulo V. 2006. Indigenous knowledge of zootherapeutic use of vertebrate origin by the Ao Tribe of Nagaland. J Hum Ecol 19 (3): 163-167. DOI: 10.1080/09709274.2006.11905874.

Kalita D, Dutta M, Islam NF. 2005. Few plants and animal-based folk medicines from Dibrugarh district, Assam. Indian J Tradit Knowl 4 (1): 181-185

Kang S, Phipps M. 2003. A Question of Attitude: South Korea's Traditional Medicine Practitioners and Wildlife Conservation. $1^{\text {st }}$ Eds. Traffic East Asia, Hong Kong.

Kendie FA, Mekuriaw SA, Dagnew MA. 2018. Ethnozoological study of traditional medicinal appreciation of animals and their products among the indigenous people of MetemaWoreda, North-Western Ethiopia. J Ethnobiol Ethnomed. DOI: DOI: 10.1186/s13002-0180234-7.

Laloo RC, Kharlukhi L, Jeeva S, Mishra BP. 2006. Status of medicinal plants in the disturbed and the undisturbed sacred forests of Meghalaya, northeast India: population structure and regeneration efficacy of some important species. Cur Sci 90: 225-231.

Lalramnghinglova H. 1999. Ethnobiology in Mizoram state: Folklore medico-zoology. Bull Indian Inst Hist Med 29: 123-148.

Mahawar MM, Jaroli DP. 2008. Traditional zootherapeutic studies in India: A review. J Ethnobiol Ethnomed 4 (1): 17. DOI: DOI: 10.1186/1746-4269-4-17.

Mao AA, Hynniewta TM, Sanjappa M. 2009. Plant wealth of Northeast India with reference to ethnobotany. Indian J Trad Know 8 (1): 96103.

Marques JGW. 1997. Fauna medicinal: recuro do ambiente on ameaca a biodiversity? Mutim 1 (1): 4.

Mihsill KRR, Keshan B. 2017. Ethno-zoological practices by Khasis, an indigenous tribe of Meghalaya, India. NEHU J 15 (1): 89-96.

Ngaomei G, Singh EJ. 2016. Traditional knowledge of therapeutic use of animals by Rongmei Tribe, Manipur, India. Int J Sci Eng Res 7 (8): 1982-1991.

Pandey BB, Duarah DK, Sarkar N. 1999. Tribal Village Council of Arunachal Pradesh, Directorate of Research, Govt. of Arunachal Pradesh, Itanagar.

Polat R, Cakilcioglu U, Kaltalioglu K, Ulusan MD, Turkmen Z. 2015. An ethnobotanical study on medicinal plants in Espiye and its surrounding (Giresun-Turkey). J Ethnopharmacol 163: 1-11. DOI: 10.1016/j.jep.2015.01.008. 
Prakash N, Ansari MA, Punitha P, Sharma PK. 2014. Indigenous traditional knowledge and usage of folk biomedicines among Rongmei tribe of Tamenglong district of Manipur, India. Afr J Tradit Complement Altern Med 11 (3): 239-247. DOI: 10.4314/ajtcam.v11i3.34.

Ragupathy S, Newmaster SG, Maruthakkutti M, Velusamy B, Ul-Huda MM. 2008. Consensus of the 'Malasars' traditional aboriginal knowledge of medicinal plants in the Velliangiri holy hills, India. J Ethnobiol Ethnomed 4 (1), 8. DOI: 10.1186/1746-4269-4-8.

Ragupathy S, Newmaster SG. 2009. Valorizing the 'Irulas' traditional knowledge of medicinal plants in the Kodiakkarai Reserve Forest, India. J Ethnobiol Ethnomed 5 (1), 10. DOI: 10.1186/1746-4269-510.

Ripunjoy S, Indira B. 2012. Indigenous knowledge and bioresource utilization among the Tai Khamyangs of Assam, North-east India Indian Res J Bio Sci 1 (7): 38-43.

Rodriguez E, Levin DA. 1976. Biological parallelisms of repellents and attractants in higher plants and arthropods. In: Wallace JW, Mansell RL (eds) Biochemical Interaction Between Plants and Insects Volume 10. Recent Advances in Phytochemistry. Plenum Press, New York. DOI: $10.1007 / 978-1-4684-2646-5$ 5.

Rosner F. 1992. Pigeons as a remedy for jaundice. J Med 92 (5): 189-192.

Saikia AP, Ryakala VK, Sharma P, Goswami P, Bora U. 2006. Ethnobotany of medicinal plants used by Assamese people for various skin ailments and cosmetics. J Ethnopharmacol 106: 149-157. DOI 10.1016/j.jep.2005.11.033.

Saio V, Upadhyay VP. 2018. Sustainable development and biodiversity conservation in North-East India: A review. Plant Sci Res 40 (1\&2) 56-66.

Sajem AL, Gossai K. 2006. Traditional use of plants by the Jaintia tribes in North Cachar Hills district of Assam, Northeast India. J Ethnobio Ethnomed 2 (1): 33. DOI: 10.1186/1746-4269-2-33.

Sarmah R, Arunachalam A, Melkania M, Mazumder M, Adhikari D. 2006. Ethno-medico-botany of Chakmas in Arunachal Pradesh, India. Indian For 132 (4): 474-484.

Sawian JT, Jeeva S, Lyndem FG, Mishra BP, Laloo RC. 2007. Wild edible plants of Meghalaya, North-east India. Nat Prod Radian 6 (5) 410-426.

Sen S, Chakraborty R, De B, Devanna N. 2011. An ethnobotanical survey of medicinal plants used by ethnic people in West and South district of Tripura, India. J For Res 22 (3), 417. DOI: 10.1007/s11676-0110184-6.

Sharma M, Sharma CL, Debbarma J. 2014. Ethnobotanical Studies of Some Plants used by Tripuri Tribe of Tripura, NE India with Special Reference to Magico Religious Beliefs. Intl J Plant Anim Environ Sci 4 (3): $518-528$

Sikdar M, Dutta U. 2008. Traditional phytotherapy among the Nath people of Assam. Stud Ethno-Med 2 (1): 39-45. DOI: 10.1080/09735070.2008.11886313.

Silambarasan R, Ayyanar M, 2015. An ethnobotanical study of medicinal plants in Palamalai region of Eastern Ghats, India. J. Ethnopharmacol 172: 162-178. DOI: 10.1016/j.jep.2015.05.046

Singh KK, Singh RKG, Sharma SK, Loitonjam A. 1998. Ethnozoological study of vertebrates among the Meitei community of Manipur. Uttar Pradesh J Zool 18 (1): 19-26.

Solanki GS, Chutia P. 2004. Ethno-zoological and socio-cultural aspect of Monpas of Arunachal Pradesh. J Human Ecol 4: 251-254. DOI: 10.1080/09709274.2004.11905701.

Solanki GS, Chutia P. 2009. Studies on Ethno-Medicinal Aspects and Zoo-Therapy in Tribal Communities in Arunachal Pradesh, India. Int J Ecol Environ Sci 35 (1): 67-76.

Solanki GS, Lalchhandama D, Lalnunpuii. 2016. Use Pattern Of Faunal Resources By Tribal And Its Impact On Biodiversity In Dampa Tiger Reserve In Mizoram, India. J Bioresour 3 (1): 24-29.
Solanki GS. 2002. Socio-cultural and faunal diversity of Arunachal Pradesh. Himal J Environ Zool 16 (2): 159-170.

Solanki GS. 2006. Diversity in Use Pattern of Faunal Resources in Tribal Communities in Arunachal Pradesh. [Final Technical Report]. G.B.Pant Institute of Himalayan Environment and Development, Kosi-Katarmal, Almora. [Indian]

Solanki GS, Chongpi B, Kumar A. 2004. Ethnology of Nyishi tribes and wildlife of Arunachal Pradesh. Arunachal Forest News 20: 74-86.

Solanki GS, Chutia P, Singh OP 2005. Ethnozoology of Nyishi tribe and its impacts on biodiversity. Arunachal Univ Res J 8 (1): 89-100.

Teron R, Borthakur SK. 2012. Traditional Knowledge of Herbal Dyes and Cultural Significance of Colors among the Karbis Ethnic Tribe in Northeast India. Ethnobot Res Appl 10: 593-603

Teronpi V, Singh, HT, Tamuli AK, Teron R. 2012. Ethnozoology of the Karbis of Assam, India: Use of ichthyofauna in traditional healthcare practices. Ancient Sci Life 32 (2): 99-103. DOI: 10.4103/02577941.118547.

Tiwari BK, Tynsong H Lynser MB. 2010. Forest Management Practices of the Tribal People of Meghalaya, North-East India. J Trop For Sci 22 (3): 329-342.

Trivedi PC. 2002. Ethnobotany: An overview. In: Trivedi PC (ed) Ethnobotany Volume 1. Aavishkar Publisher, Jaipur.

Turnia I, Prasad SB. 2017. Traditional zootherapeutic practices by the indigenous Khasi natives of Sohiong village, East Khasi hill district, Meghalaya, India. Asian J Complement Altern Med 1: 1-8.

Tynsong H, Dkhar M, Tiwari BK. 2012a. Traditional knowledge-based management and utilization of bio-resources by war Khasi tribe of Meghalaya, North-east India. Indian J Innov Dev 1 (3): 162-174.

Tynsong H, Tiwari BK, Dkhar M. 2012b. Traditional knowledge associated with traditional harvesting bird harvesting of War Khasi Meghalaya. Indian J Tradit Know 11: 334-341.

Tynsong H, Tiwari BK, Lynser M. 2006. Medicinal plants of Meghalaya. Med Net New 6: 7-10.

Tynsong H, Tiwari BK. 2008. Traditional knowledge associated with fish harvesting practices of War Khasi community of Meghalaya. Indian J Tradit Know 7: 618-623.

Tynsong H, Dkhar M, Tiwari BK. 2020. Review: Traditional ecological knowledge of tribal communities of North-east India. Biodiversitas 21 (7): 3209-3224. DOI: 10.13057/biodiv/d210743.

Verma AK, Prasad SB, Rongpi T, Arjun J. 2014. Traditional healing with animals (zootherapy) by the major ethnic group of Karbi Anglong district of Assam, India. Intl J Phar Pharm Sci 6 (8): 593-600

von Fürer-Haimendorf C. 1982. Tribes of India: The Struggle for Survival. University of California Press, Berkeley.

Werner D. 1970. Healing in the Sierra Madre. The Natural History 79 (9): 61-66.

World Health Organization (WHO). 1993. Guideline on the conservation of medicinal plants. WHO, Geneva.

World Health Organization (WHO). 2014. Traditional medicine strategy 2014-23. WHO, Geneva.

World Resources Institute (WRI). 2000. World Resources Report (20002001). People and ecosystems: The fraying web of life. World Resources Institute, Washington DC.

Yirga G, Teferi M, Gebreslassea Y. 2011. Ethnozoological study of traditional medicinal animals used by the people of Kafta-Humera District, Northern Ethiopia. Intl J Med Med Sci 3(10): 316-320

Young A. 1983. The relevance of traditional medical culture in modern primary health care. Soc Sci Med 17: 1205-1212. DOI: 10.1016/02779536(83)90013-8

Zhimomi KK. 2004. Politics and Militancy in Nagaland. Deep and Deep Publications Pvt. Ltd., New Delhi. 